\title{
Technè
}

La science au service de l'histoire de l'art et de la préservation des biens culturels

$45 \mid 2017$

Bronzes grecs et romains : études récentes sur la statuaire antique

\section{The New York Sleeping Eros: A Hellenistic Statue and Its Ancient Restoration}

L'Éros endormi de New York, une statue hellénistique et sa restauration antique

\section{Seán Hemingway and Richard Stone}

\section{(2) OpenEdition \\ Journals}

Electronic version

URL: http://journals.openedition.org/techne/1266

DOI: $10.4000 /$ techne. 1266

ISSN: 2534-5168

Publisher

C2RMF

\section{Printed version}

Date of publication: 1 May 2017

Number of pages: $46-63$

ISBN: 978-2-7118-6408-9

ISSN: 1254-7867

Electronic reference

Seán Hemingway and Richard Stone, «The New York Sleeping Eros: A Hellenistic Statue and Its Ancient Restoration », Technè [Online], 45 | 2017, Online since 19 December 2019, connection on 10 December 2020. URL : http://journals.openedition.org/techne/1266 ; DOI : https://doi.org/10.4000/ techne.1266

a revue Technè. La science au service de l'histoire de l'art et de la préservation des biens culturels est mise à disposition selon les termes de la Licence Creative Commons Attribution - Pas d'Utilisation Commerciale - Pas de Modification 4.0 International. 


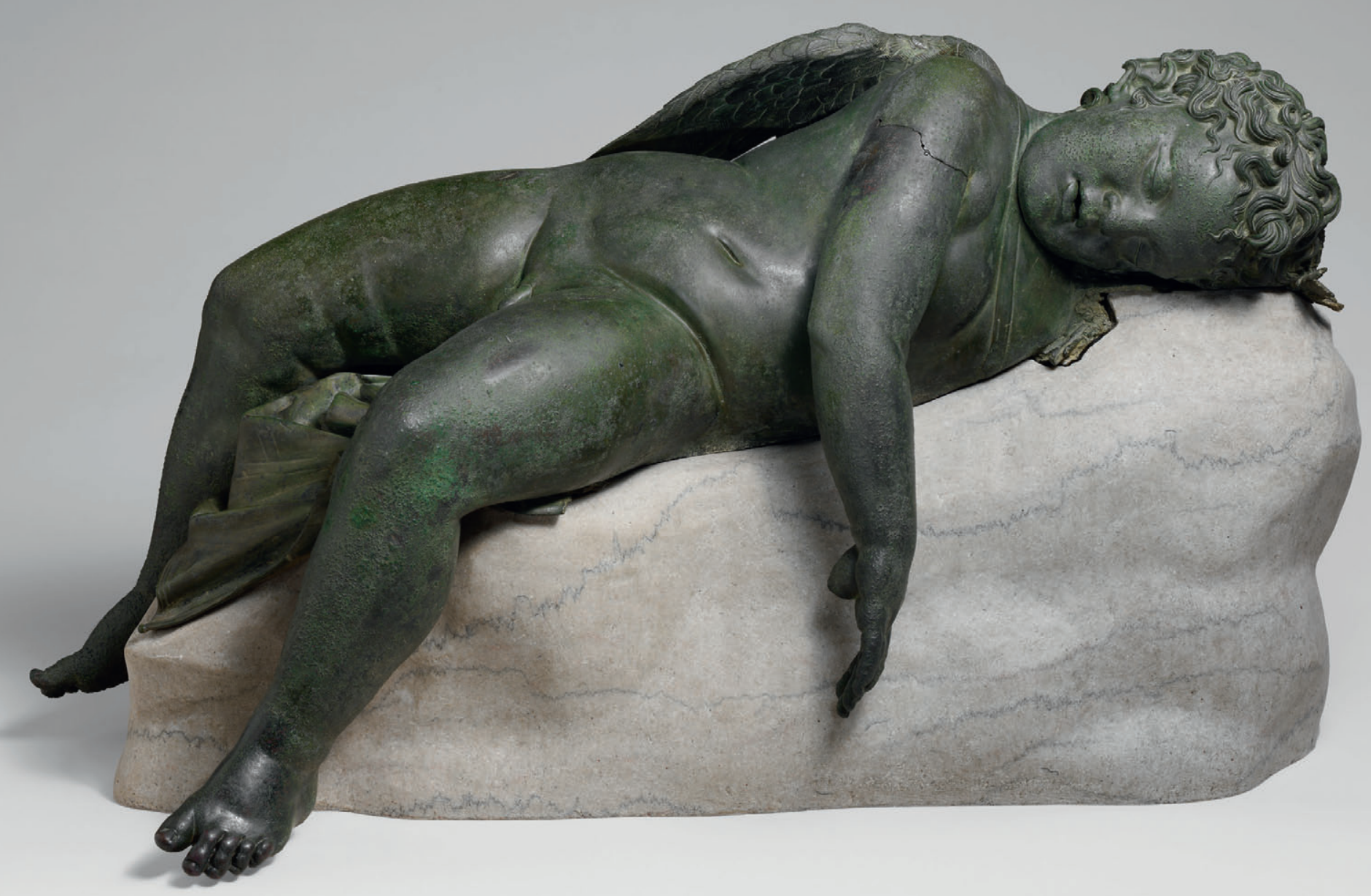

Fig. 1. Front view of Statue of Sleeping Eros, Greek, Hellenistic period,

3rd-2nd century B.C. Bronze. Length 85,4 cm. The Metropolitan Museum of Art,

New York, Rogers Fund, 1943 (43.11.4). ( ) The Metropolitan Museum of Art. 
Seán Hemingway

Richard Stone
The New York Sleeping Eros: A Hellenistic Statue and Its Ancient Restoration
Abstract. The Bronze Statue of Sleeping Eros in the Metropolitan Museum has long been recognized as one of the finest bronze statues to survive from antiquity. It was first published by Gisela Richter as an original Hellenistic sculpture or very close replica dated between 250 and 150 B.C. Many subsequent scholars tend to agree with Richter's assessment although not her precise dating. Others believe it to be a very fine Roman copy of one of the most popular sculptures ever made in Roman Imperial times known from hundreds of copies, variants and adaptations. This article presents a new assessment based on careful scientific and technical examinations of the statue itself and a close study of other existing sculptures of this type. The research supports Richter's

identification of the statue as a Hellenistic work, but also makes apparent that it was restored in antiquity, most likely in the Early Imperial period. Consideration of the cult and mythology of Eros, other major Late Classical and Hellenistic sculptures, as well as the different meanings of the Sleeping Eros in later periods, enable a more cogent understanding of the original display of the Metropolitan Museum's bronze statue of Sleeping Eros and its significance in antiquity.

Keywords. Ancient repair, Aphrodite, Eros, god of love, Hellenistic bronze sculpture.
L'Éros endormi de New York, une statue

hellénistique et sa restauration antique
Résumé. L'Éros endormi conservé au Metropolitan Museum of Art est reconnu depuis longtemps parmi les plus beaux grands bronzes antiques parvenus jusqu'à nous. Gisela Richter, la première à l'avoir publié, le considérait comme un original de la période hellénistique ou une réplique fidèle, et le datait entre 250 et 150 av. J.-C. Depuis, de nombreux auteurs se sont accordés sur cette identification tout en ayant quelques divergences sur la datation. D'autres pensent qu'il s'agit d'une très bonne copie romaine d'une des sculptures les plus prisées de la période romaine impériale, connue par des centaines de copies, variantes et adaptations. Cet article présente une nouvelle évaluation fondée sur des examens scientifiques et techniques approfondis de la statue elle-même et sur une observation minutieuse d'autres sculptures du même type. Ces travaux tendent à confirmer l'hypothèse hellénistique avancée par Gisela Richter, mais révèlent également que la statue a fait l'objet d'une restauration dans l'Antiquité, sans doute au début de la période impériale. Le culte et la mythologie d'Éros, d'autres sculptures importantes de la période hellénistique et de l'Antiquité tardive, ainsi que les différentes significations de l'Éros endormi à des époques ultérieures éclairent notre compréhension de l'installation d'origine du bronze actuellement à New York et de ses enjeux dans l'Antiquité.

Mots-clés. Restauration antique, Aphrodite, Éros, dieu de l'Amour, sculptures en bronze hellénistiques.

\section{The Mythology and Iconography of Eros}

The Bronze Statue of Sleeping Eros in the Metropolitan Museum of Art (fig. 1) belongs to a long tradition of Greek Eros sculptures and in many ways is a quiet but radical departure from them. Famous statues of Eros made by major Classical sculptors would have been known to the artist who created the Metropolitan's bronze statue of Eros sleeping. Phidias and Alcamenes both created Eros statues although relatively little is known about what the sculptures looked like ${ }^{1}$. Skopas sculpted an Eros as part of a group of statues of Eros, Pothos (Longing) and Himeros (Yearning) that was set up at a sanctuary of Aphrodite at Megara ${ }^{2}$. Callistratus, De
Statuis 3, described Praxiteles's bronze Eros at Thespiae in Boeotia as marvelously life-like, a joyous archer with an ardent gaze, large wings and easy pose that made flight seem possible. The bronze Eros by Lysippos, made ca. 338-335 B.C., also dedicated to the god at Thespiae, represented the god as a winged youth stringing his bow (fig. 2). Eros, the archer, prepares to wound. It is a momentary pose that captures the god's double nature: desire can bring happiness or it can destroy by unsettling wisdom.

There were many different myths about the lineage of Eros and during the Classical period another myth of Eros began to take hold ${ }^{3}$. The primordial Eros was brought into the Olympian pantheon and became the child of Aphrodite

Seán Hemingway, Curator, Greek and Roman Art, The Metropolitan Museum of Art, New York, NY (sean.hemingway@metmuseum.org). Richard Stone, Conservator Emeritus, The Metropolitan Museum of Art, New York, NY. 


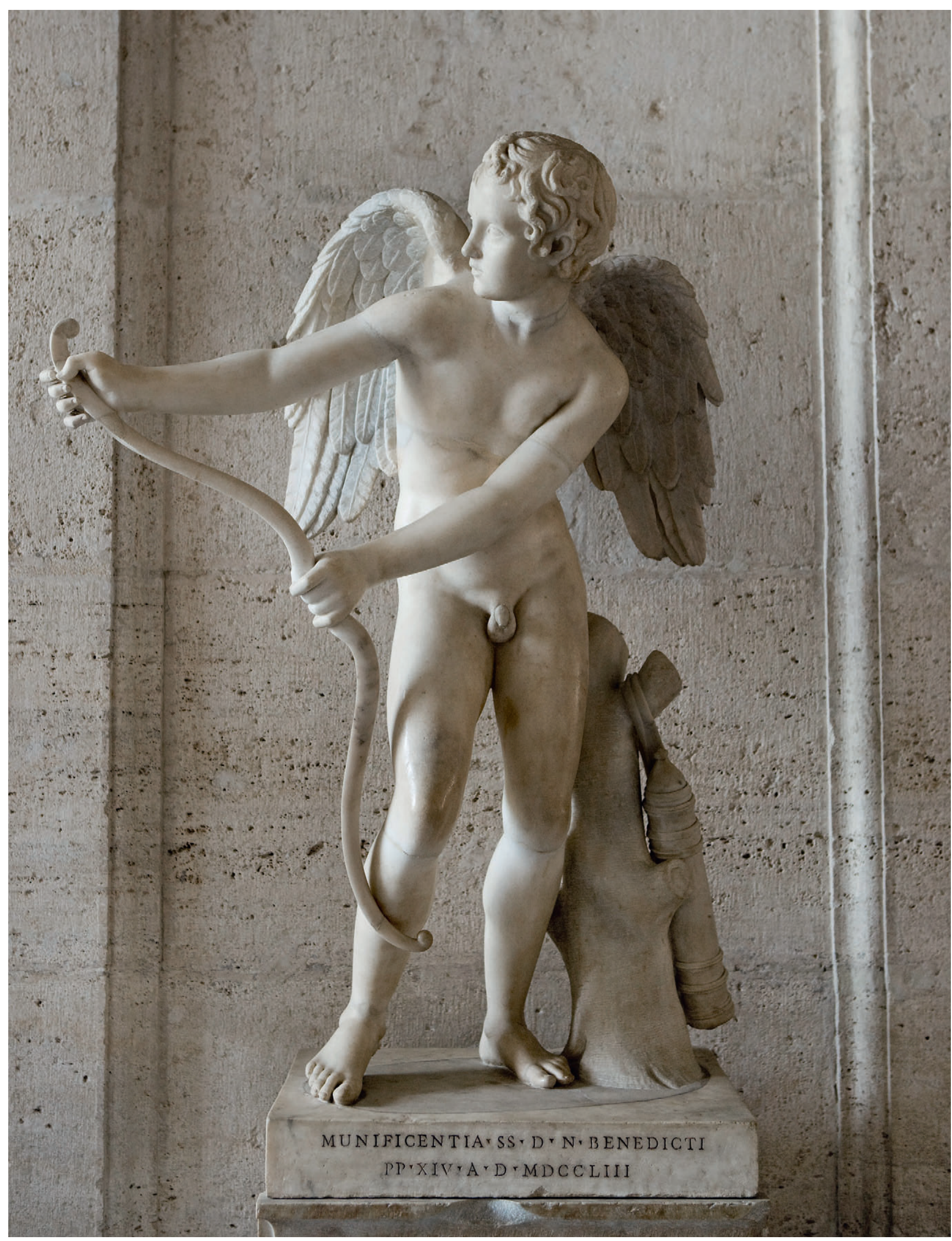

Fig. 2. Statue of Eros Stringing his Bow, Roman copy of a Greek bronze statue by Lysippos of ca. 338-335 B.C. Found at Hadrian's Villa near Tivoli. Roman, Early Imperial period, 1st or early 2nd century A.D. Marble. The Capitoline Museums, Rome. () Vanni Archive/Art Resource, New York. 
and Ares, the god of war. The myth of Aphrodite and Ares's love affair is known as early as Homer's Odyssey, 8.266-369, though it does not mention Eros as a result of their union. Aphrodite and Ares are associated in regional Greek sanctuaries from at least the Archaic period ${ }^{4}$. However, the earliest mention of Eros in the myth of Aphrodite and Ares appears in a fragment attributed to the 5 th century B.C. poet Simonides ${ }^{5}$. It was not until the 4 th century B.C., especially in the Hellenistic period, that the myth became popular. While there are a few representations of Eros as a child in Classical art, it is not until the Hellenistic period that he is predominantly portrayed as a child, which is surely a visual counterpart to the myth of Aphrodite and Ares and its literary tradition. The Sleeping Eros, certainly among the most successful images of the god from the Hellenistic period, must have significantly reinforced the myth of the union of Ares and Aphrodite bearing $\operatorname{Eros}^{6}$.

\section{The Place of the New York Sleeping Eros in the Replica Series - Its Original Date of Manufacture and Provenance}

The Metropolitan's Sleeping Eros is the finest example of its kind. In a careful study of the representations of Sleeping Eros, Magdalene Söldner catalogued 349 examples dating from as early as the 3rd century B.C. to the 4th century A.D. The vast majority of the works in bronze, marble and terracotta are from the Roman Imperial period. Söldner identified eleven different variations of Sleeping Eros and the type associated with the Metropolitan's bronze statue appears to be the earliest. There exist nearly forty replicas of this particular variant, which is known as the New York type after the Museum's statue ${ }^{7}$. The Metropolitan's statue has been considered the original or a Hellenistic original by Gisela Richter in an important article in the American Journal of Archaeology in 1943, and has been dated to between 250-150 B.C. ${ }^{8}$ Many scholars generally agree with Richter's assessment but often argue for different dates within the Hellenistic period $^{9}$. Jean Marcadé, for example, dates it not later than the middle of the 3rd century B.C. citing similarities to the Barberini Faun especially its open composition and the torsion of its torso ${ }^{10}$. Magdalene Söldner argues for an even earlier date between 270-260 B.C. ${ }^{11}$ The naturalism of the Sleeping Eros compares with other Hellenistic sculptures of the 3rd or 2nd century B.C. such as the Baker Dancer and the prototype of the Old Market Woman known from a number of copies of the Early Imperial period, and sleep becomes a popular theme in large-scale sculptures during the first centuries of the Hellenistic period. Indeed, numerous scholars from Richter ${ }^{12}$ to Ridgway ${ }^{13}$ have made nuanced comparisons in an effort to narrow the date of the Metropolitan's bronze statue of Sleeping Eros. The problem lies in the fact that there are relatively few securely dated Hellenistic sculptures and Hellenistic sculptors borrowed freely from the styles of previous periods. The precise dating of most Hellenistic sculptures is difficult unless the work is tied to a particular historical event ${ }^{14}$. Carol Mattusch cautions dating the Metropolitan's statue precisely, suggesting that "we can only tentatively conclude that the Eros is no earlier in date than the Hellenistic period, and we can make no assumptions about how late it might be ${ }^{15}$." Lucilla Burn, in her recent book on Hellenistic art, suggests that it could date to the Hellenistic or Roman period ${ }^{16}$. When the Metropolitan's Sleeping Eros was installed in the new Hellenistic and Roman galleries in 2007, it was dated very broadly as a Hellenistic work or a particularly fine Roman copy of the Augustan period ${ }^{17}$. The technical analysis presented in this paper supports the identification of the Metropolitan's statue as a Hellenistic work, and stylistic analysis only allows a broad date of the 3rd century or 2nd century B.C.

The Metropolitan Museum of Art acquired the Sleeping Eros in 1943 from the New York dealer Joseph Brummer, who had purchased it in Paris in 1930 from the Greek dealer E. Gelidakis. It is said to have come from the island of Rhodes. While it is not possible to confirm this provenance it is nonetheless worth considering. Rhodes was a famous place for bronze working in the Hellenistic period, home to one of the seven wonders of the ancient world; the Colossus, a giant Early Hellenistic bronze statue of the sun god Helios, towered over the harbor of its main town ${ }^{18}$. Recent excavations on Rhodes have unearthed evidence of Hellenistic bronze foundries, but there is very little extant large-scale bronze sculpture from that period on the island, which compares to the Metropolitan's Sleeping Eros ${ }^{19}$. One of the few comparanda is a statue in the Antikensammlungen in Berlin known as the Praying Youth that is likely an Early Hellenistic work. It depicts an athlete, either a runner or jumper, who was victorious in the games ${ }^{20}$. In the Metropolitan's collection, a very fine Early Imperial portrait statue of an aristocratic boy, also said to come from Rhodes, demonstrates that very high quality bronze sculpture continued to be made on Rhodes into the Augustan Age $^{21}$.

\section{Scientific and Technical Analysis}

Gisela Richter offered some comments about how the Sleeping Eros was made but since the publication of her study, seventy years ago, practically no technical analysis had been done. The present study, utilizing X-radiography, chemical and metallographic analyses, non-destructive X-ray fluorescence analyses, and careful visual examination after new cleaning of parts of the interior presents a more accurate understanding of how the statue was made. Of particular importance is the discovery that a large section of the drapery appears to have been restored in antiquity, likely during the Roman Imperial period.

In antiquity, all known large-scale bronze statues were piece-cast and then the parts were typically welded together ${ }^{22}$. The statue of Sleeping Eros in the Metropolitan is no exception as it was cast in pieces that were then joined together. While burial accretions on the exterior of the statue were removed 
prior to its acquisition by the Museum, accretions on the interior were left in situ ${ }^{23}$. The statue is open at the bottom and as such offers unusual access to its interior (fig. 3). Careful visual examination combined with X-radiography and selective cleaning of the interior surface enabled the identification of all the cast sections of the statue and the locations of where the pieces were joined together. The statue, as it is preserved today, was made in seven pieces: head, body with left wing, left arm, right wing, left leg, right leg and the drapery (fig. 4$)^{24}$. It is interesting to note that the seven separately cast sections are all roughly equal in size, giving, it would seem, a sense of the amount of metal preferred for a pour in the foundry that cast the statue. Ancient foundries needed to limit the size of the cast sections because of their limitations for melting and keeping molten large quantities of metal.

The left arm of the statue is broken just above where it was joined in antiquity near the shoulder. Considerable excess metal visible on the interior near the break has a green patina and is likely remains of flow weld metal used to join the arm in antiquity. Since the statue is open at the bottom, it is in many ways like a deep relief (see fig. 3). Consequently, the founder had unusual access to the interior of the statue, enabling him to join the head, legs and right wing to the body from the inside instead of the outside as was more typically necessary. This condition helps to explain the economy of metal used in the joins of the statue. The head is attached only along part of the back of the neck by what must be a flow weld that has very little excess metal. Narrow gaps were left open on the underside of the chin and part of the back. The slightly rougher surface at the back of the neck may be an indication of this join on the exterior. After the recent cleaning, the excess metal of the flow weld join between the body and the left leg is clearly visible on the interior as is part of the edge of the two cast sections at the join. A similar join is visible on the right leg with less excess metal visible. Likewise, the location of the weld used to attach the top of the right wing and a second weld near the tip of the wing are clearly visible from the interior. The smooth splattered metal of the weld near the tip of the wing looks like it was poured from within and must have overflowed around the area of the join thus creating a broader bond on the interior.

The fact that most of the interior of the statue adheres closely to the form of its exterior is indicative of the indirect lost wax casting process ${ }^{25}$. However, an X-radiograph of the head shows that the fine curls of hair are solid and would thus have been worked in wax and then applied to the figure (fig. 5). This is individualized work that would have been unique to the sculpture.

Square core pin holes are visible in X-radiographs and on the interior of the head, body, legs and drapery (fig. 6$)^{26}$. Narrow fins around the pin holes on the interior indicate that the core pins were most likely heated and pushed through the wax model from the exterior. There also appears to be a plug in the proper left big toe, which may have been a place where core material was introduced (see fig. 6). During the cleaning of the interior body, two small fragments of the clay core were identified adhering to the interior, confirming that clay was used as the core material. However, small globules of metal on the interior of the drapery between the legs, visible in the X-radiograph, indicate that the core for this cast

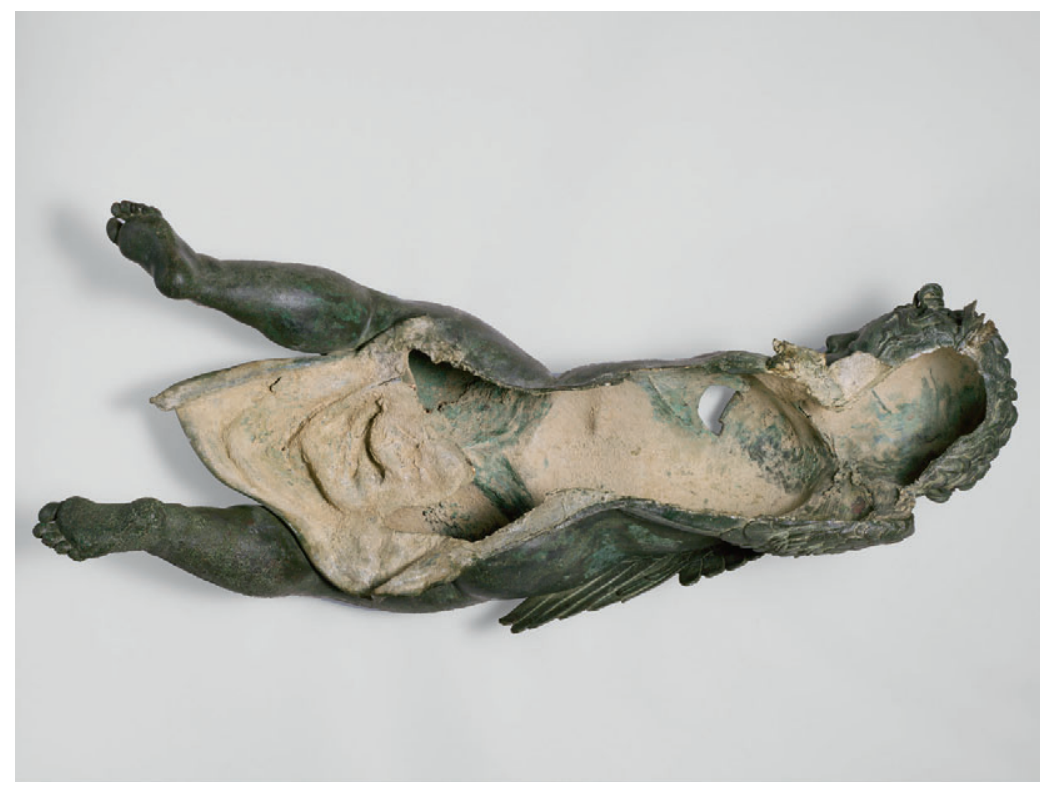

Fig. 3. Underside of Statue of Sleeping Eros. The Metropolitan Museum of Art, New York, Rogers Fund, 1943 (43.11.4). (C) The Metropolitan Museum of Art.

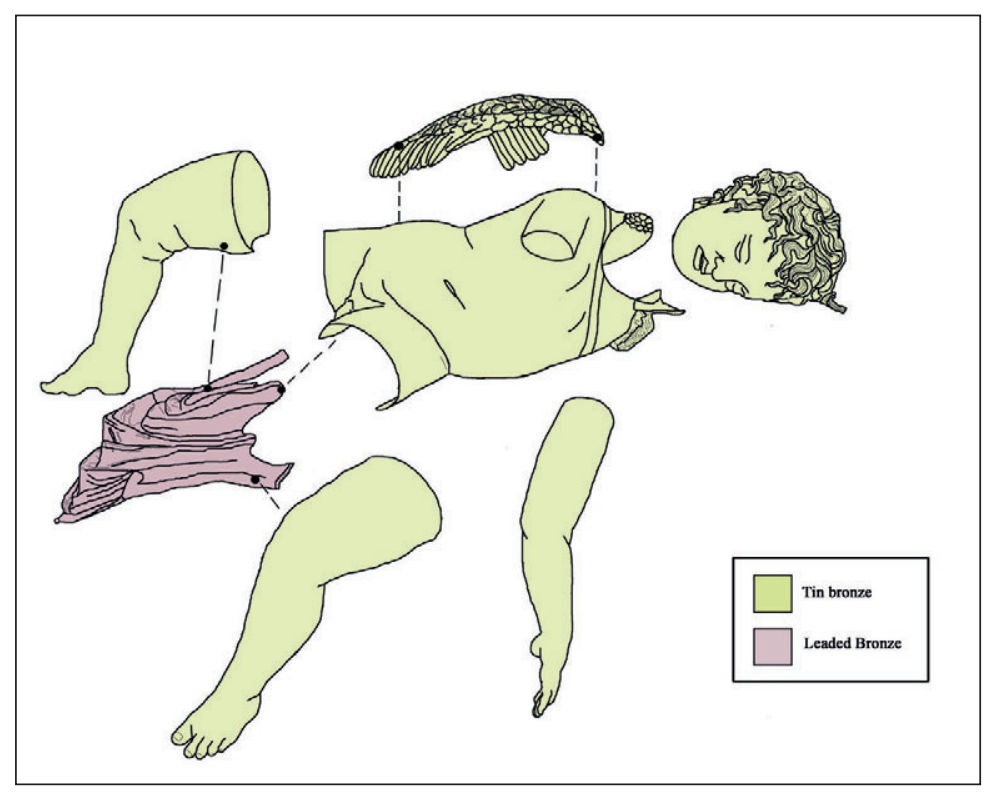

Fig. 4. Drawing of Cast Sections of the Metropolitan's Bronze Statue of Sleeping Eros and their alloys. Drawing by Allia Benner. 


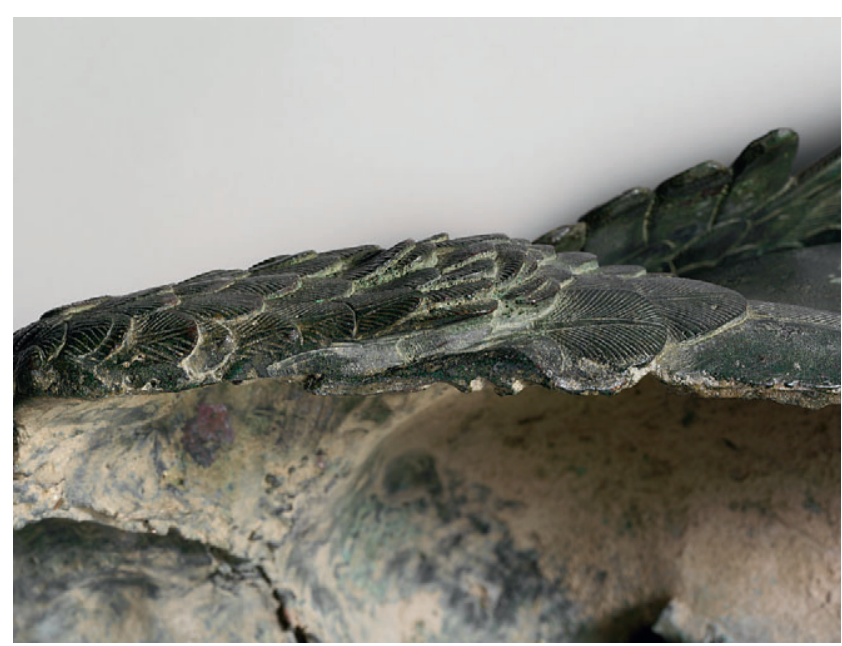

Fig. 8. Detail of groove on underside of left wing for attachment of base. The Metropolitan Museum of Art, New York, Rogers Fund, 1943 (43.11.4). (c) The Metropolitan Museum of Art.

of Shelby White and Leon Levy, the statue known as the Youth from Salamis, and the head of an athlete in the DeMenil Collection in Fort Worth ${ }^{35}$.

Seven samples were taken from various parts of the interior of the Metropolitan's Sleeping Eros. These samples were subjected to quantitative analysis using energy dispersive and wavelength dispersive X-ray spectrometry in the scanning electron microscope (SEM-EDS/WDS) in order to determine the alloy compositions. The work was carried out by Mark Wypyski in The Metropolitan Museum of Art's Department of Scientific Research. The chemical analyses from different parts of the statue revealed some surprising results (see Table 1). The samples fell into two categories. Most of the samples were typical tin bronzes with trace levels of impurities,

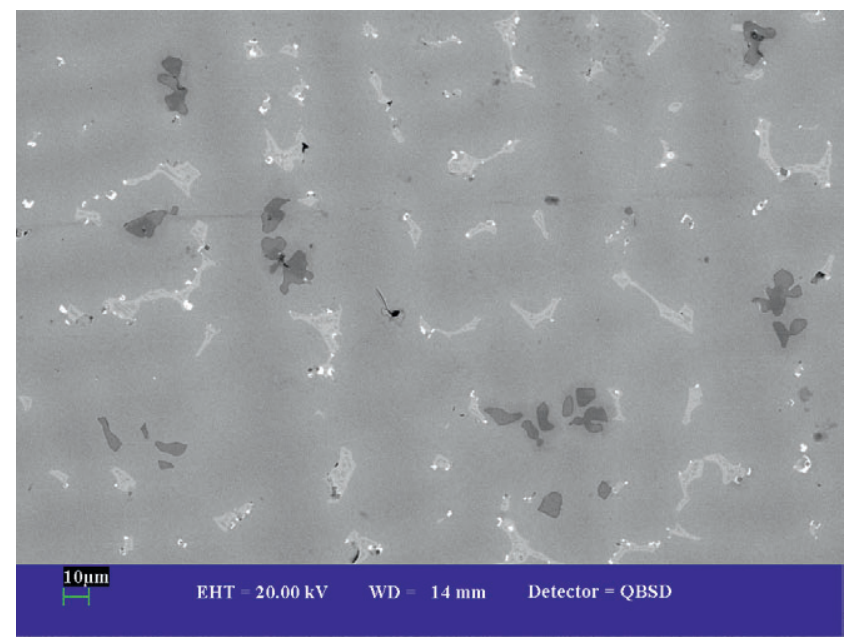

Fig. 10. Polished metallographic section of Sample 2 taken from the interior of the head. Magnification 800X. Image courtesy The Metropolitan Museum of Art, The Sherman Fairchild Center for Objects Conservation, G\&R 43.11.4. @ The Metropolitan Museum of Art.

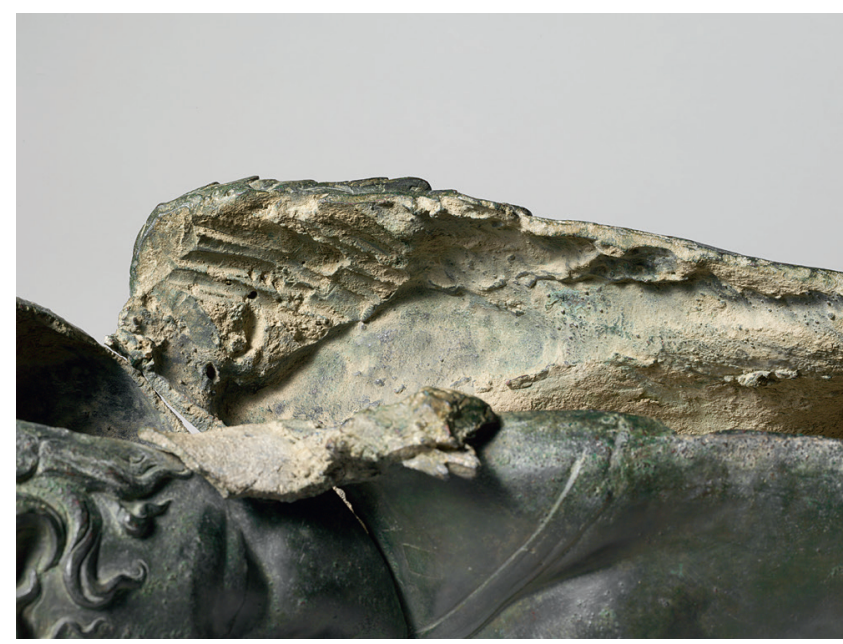

Fig. 9. Detail of interior of upper left wing with chisel marks where metal was removed for attachment to base. The Metropolitan Museum of Art, New York, Rogers Fund, 1943 (43.11.4).

(C) The Metropolitan Museum of Art.

and little or no lead, as is well represented in a polished metallographic section of sample number two taken from inside the head (fig. 10). The grain structure is clearly visible; the brighter areas represent the higher tin phases while the small white globules are traces of lead. However, two of the samples were leaded tin bronzes with a high concentration of lead, between $18-19 \%$, as illustrated in sample number three, which came from the drapery between the legs ${ }^{36}$. In the metallographic section of this sample, all of the bright areas are mostly lead (fig. 11). Interestingly, the sample from the join between the head and body contained $2 \%$ more tin. This differentiation may represent a slightly more fluid alloy used to weld the two pieces together if the variation is not due to greater oxidation of the sample. Another sample from

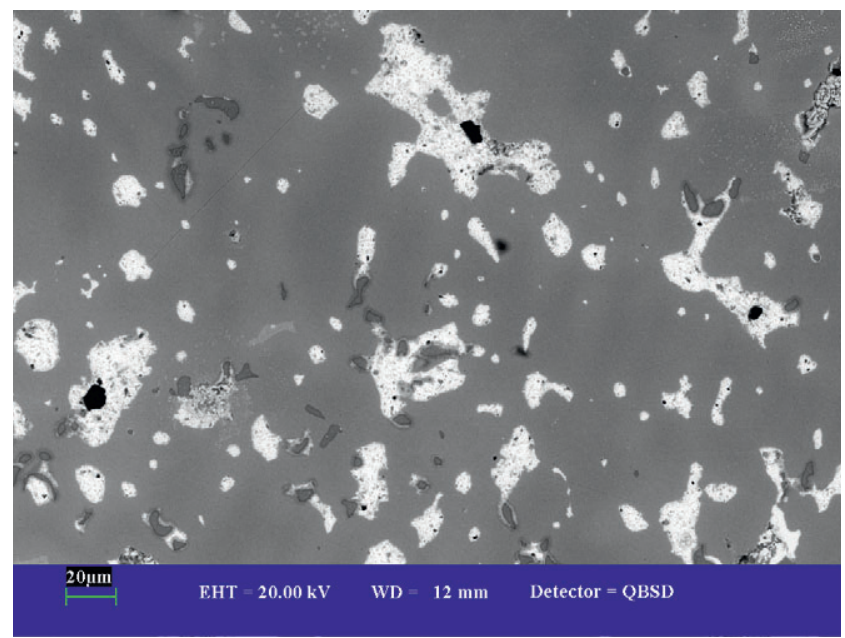

Fig. 11. Polished metallographic section of Sample 3 taken from the drapery between the legs. Magnification 800X. Image courtesy The Metropolitan Museum of Art, The Sherman Fairchild Center for Objects Conservation, G\&R 43.11.4. (C) The Metropolitan Museum of Art. 
Table 1. Chemical analysis of seven samples from the Metropolitan's Bronze Statue of Sleeping Eros (weight \%)

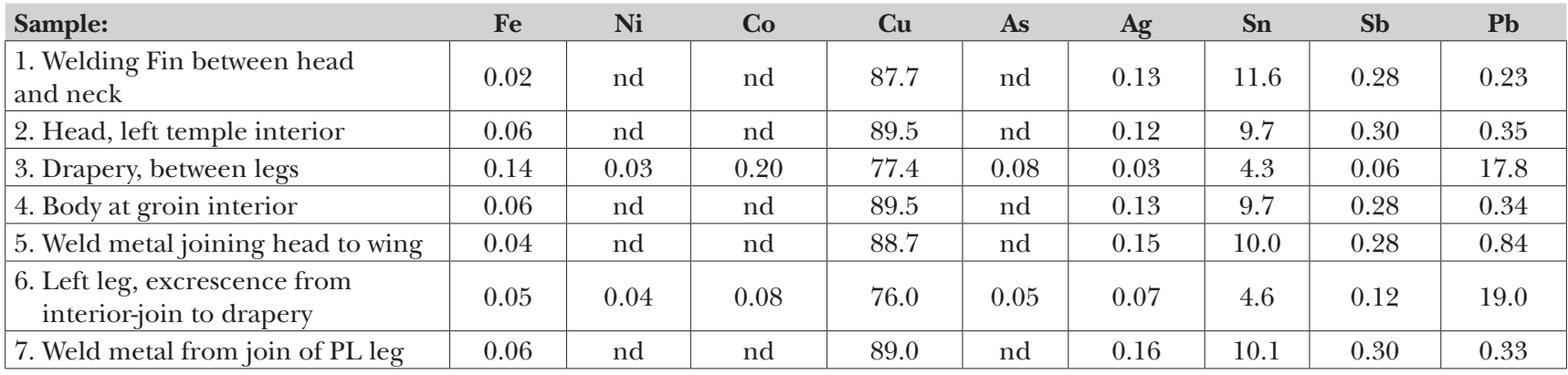

the join at the neck and a sample from the weld metal between the left leg and body did not register any significant differences from the alloy used to cast the head and body. Cast sections that were not sampled (the left arm, right wing, and left and right legs) were examined by means of a non-destructive X-ray fluorescence unit. All were found to be tin bronzes of a similar alloy to the head and body. Using the XRF unit, it was possible to identify clearly where the leaded drapery joins the unleaded drapery on the figure, which continues under much of the body at the back and demonstrates clearly that the drapery was part of the original composition. The join is also clear in an X-radiograph that distinguishes the more opaque leaded metal from the less opaque unleaded tin bronze. Even though the thickness of the bronze is consistent, the density of the lead appears more opaque in x-radiographs (fig. 12). The drapery may have been cast onto the figure since there is no clear evidence of excess metal from a weld except a spongy excrescence inside the left leg that flows from the join between the leg and drapery.

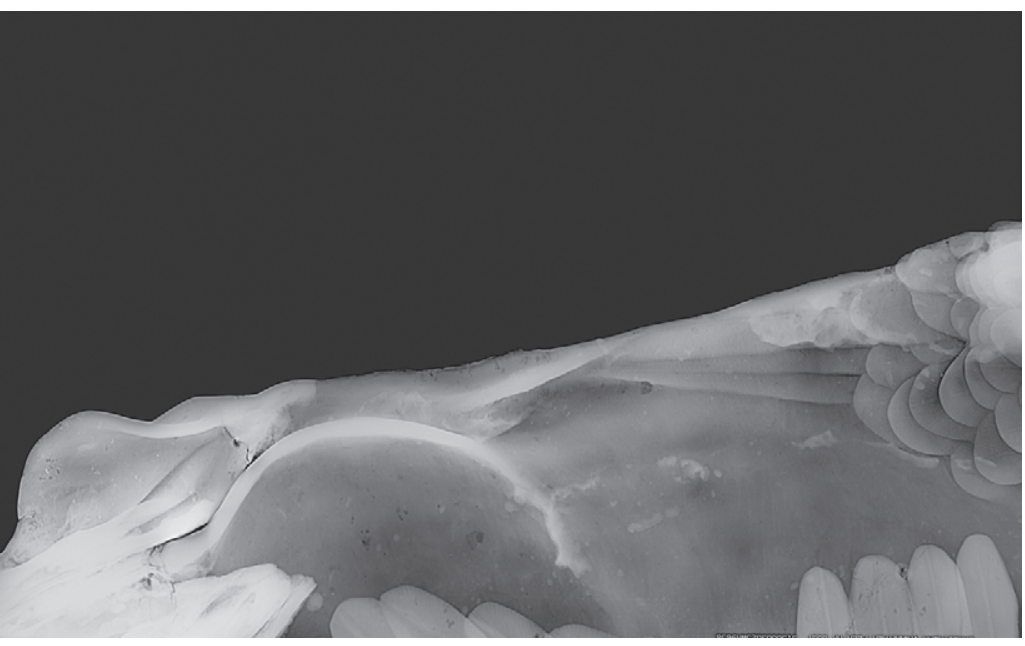

Fig. 12. X-radiograph of the join in the drapery at the back of the statue by the left leg. Image courtesy The Metropolitan Museum of Art, The Sherman Fairchild Center for Objects Conservation, G\&R 43.11.4. (C) The Metropolitan Museum of Art.
The head, body and other parts of the figure are regular tin bronzes, typical for an ancient Greek bronze sculpture of the Hellenistic period, while the drapery between the legs contains high quantities of lead, more like what one would expect of an Imperial Roman bronze sculpture ${ }^{37}$. While it is necessary to be cautious when interpreting alloy results, this variation and the apparent difference in the kind of core material used between these cast sections require some explanation. The statue may have been damaged in antiquity and then repaired at a later date, possibly in Early Imperial times when large quantities of lead commonly were added to the alloys of large-scale sculptures.

\section{Reconstructing the Missing Parts of the Sleeping Eros Statue}

The Metropolitan's statue of Sleeping Eros is remarkably well preserved (see fig. 1). It sits so well on its modern base and has become such an icon in and of itself that it is possible to forget that it lacks some parts. Besides the base, the left arm, several parts of the drapery, the quiver and bow are all missing. Careful examination of the statue in relation to other replicas from the series enables a fairly clear reconstruction of the missing parts. The closest copy to the Metropolitan's statue is a marble statue in the Palazzo Clementino of the Capitoline Museums (fig. 13), which was found in Rome and is dated to the 2nd century A.D. ${ }^{38}$ Despite its later date, the Capitoline figure closely compares with the Metropolitan's statue, particularly the position of the figure and the drapery on which the child god sleeps. However, notable differences include the hair style and the Capitoline Eros's more dynamic wings with the quiver strapped to his back between them, which is a popular variant of the type ${ }^{39}$.

Importantly, the well-preserved drapery between the legs of both statues is especially close (figs. 14-15). Both sculptures exhibit the same complex drapery pattern that must stem from the same prototype. The drapery of the Capitoline Sleeping Eros, however, is not as finely rendered. There are no press folds or fine selvage, nor is the knot at the corner preserved. Given the clear relationship between the existing 
drapery between the legs of the New York Sleeping Eros and the Sleeping Eros in the Palazzo Clementini, the other areas of drapery well-preserved on the Sleeping Eros in the Palazzo Clementini ought to provide a good indication of how to reconstruct the missing drapery of the New York Sleeping Eros. In fact, the line of drapery below the belly also corresponds closely. A small fragment of drapery on the front of the Metropolitan's Sleeping Eros can be compared to the placement of drapery on the Sleeping Eros in the Palazzo Clementini, which has a mass of drapery folds below the head bunched like a pillow and hanging down over the missing rock. A few other replicas in the New York Sleeping Eros replica series also appear to copy this drapery although less exactly. These include a first-century A.D. marble statue of Sleeping Eros from Paphos on Cyprus and a marble statue in the Delphi Archaeological Museum, which is dated to the early 2 nd century A.D. and was once used as a fountain ${ }^{40}$. The drapery scheme is also replicated in small-scale versions, like the first- or second-century A.D. bronze statuette in the Metropolitan's collection ${ }^{41}$.

The placement of the left arm of the Capitoline Sleeping Eros provides a clear picture of what the Metropolitan's Sleeping Eros's missing arm would have looked like although the quiver would have also been placed by the left arm. It is notable that the quiver strap crosses the front of the Metropolitan's Sleeping Eros like the Capitoline Sleeping Eros but then differs. It does not continue between the wings to meet the quiver which instead was placed near the head ${ }^{42}$. The feather of an arrow preserved by the head of the New York Sleeping Eros makes clear that the quiver was originally open, a more complicated rendering since each arrow would have been sculpted individually ${ }^{43}$. The open quiver adds to the sense of immediacy in the bronze statue. His bow was in hand and the quiver ready for use when Eros fell asleep. An open quiver appears on a few other examples from the replica series such as an Early Imperial marble copy in the Residenzmuseum in Munich ${ }^{44}$.

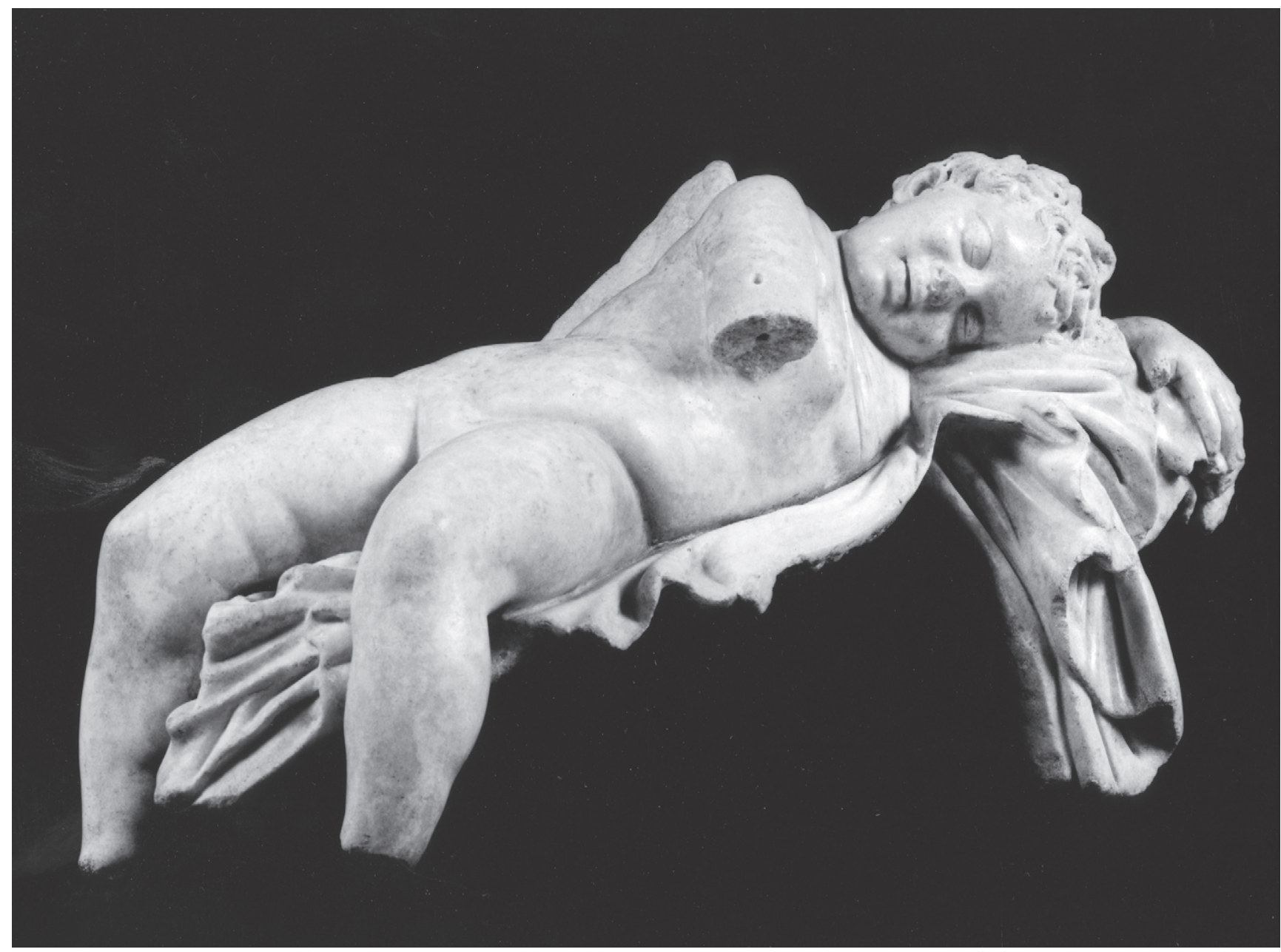

Fig. 13. Statue of Sleeping Eros, Roman copy of a Hellenistic bronze statue of the 3rd or 2nd century B.C. Roman, Imperial period, 2nd century A.D. Marble. Capitoline Museums, Rome. (c) Image courtesy of the Capitoline Museums, Rome. 


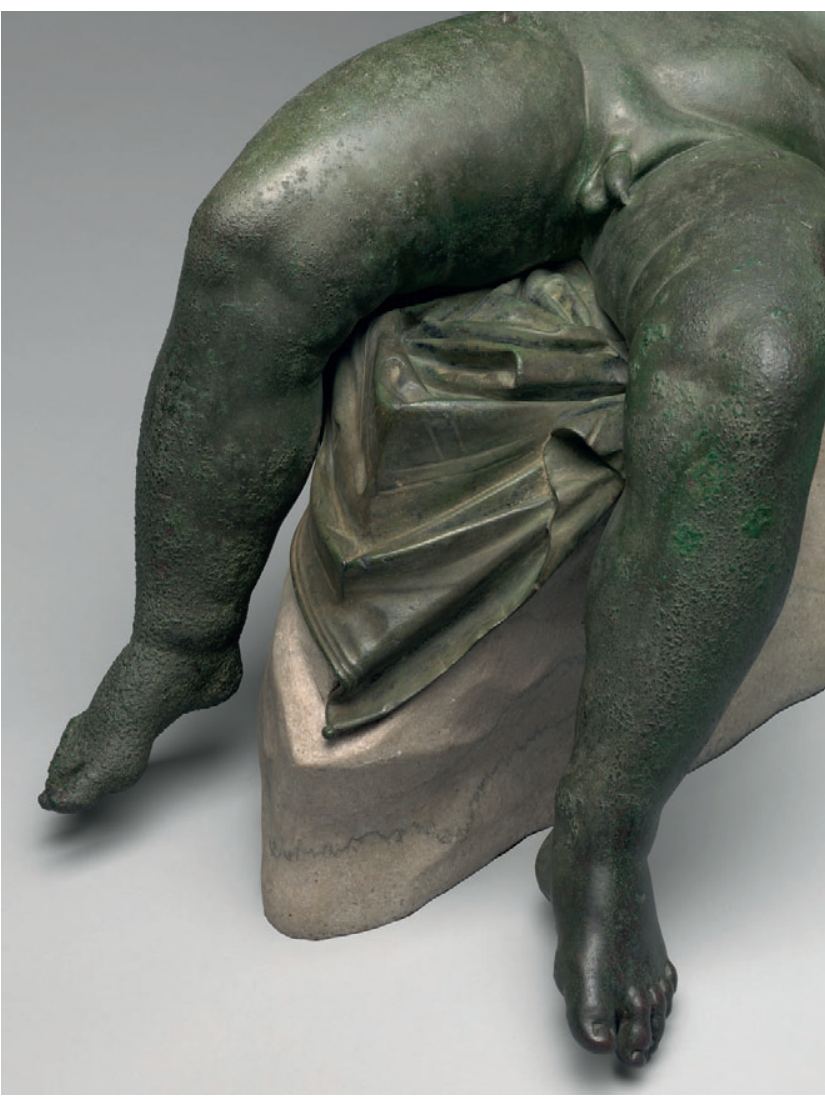

Fig. 14. Detail of the drapery between the legs of the Metropolitan's Bronze Statue of Sleeping Eros. The Metropolitan Museum of Art, New York, Rogers Fund, 1943 (43.11.4). (C) The Metropolitan Museum of Art.

What would the quiver of the Metropolitan's Sleeping Eros have looked like? It may have been ornate with relief decoration as occurs in some figures of Eros, or it may well have been of a simpler design like the quiver of the Capitoline Sleeping Eros ${ }^{45}$. Although none of the other Sleeping Eros statues of the New York type preserve the quiver by the head like the one in the Metropolitan, in many of the examples the quiver is simply not preserved at all. There is a later type of Sleeping Eros, known as the Broadlands type, which also has the quiver placed off the body and near the head ${ }^{46}$.

Relatively few of the extant replicas of the New York type preserve their bows, but two statues in Roman collections give some sense of what the bow of the Metropolitan's Sleeping Eros may have looked like and its general placement. A marble sculpture in the Vatican restored in the eighteenth century, although missing the right hand and central part of the bow, is preserved well enough to see that the bow lies just below the right hand, which may have grasped its lower part as it is now restored. In another Imperial copy in the Galleria Colonna in Rome, the bow lies on the ground near the rock and Eros's hand is over the grip ${ }^{47}$. The Metropolitan's Sleeping Eros would have had a similar small bow that matched the scale of its owner. In the Metropolitan's statue, however, the bow appears to have slipped from Eros's hand, coming to rest against the rock on which he is sleeping.

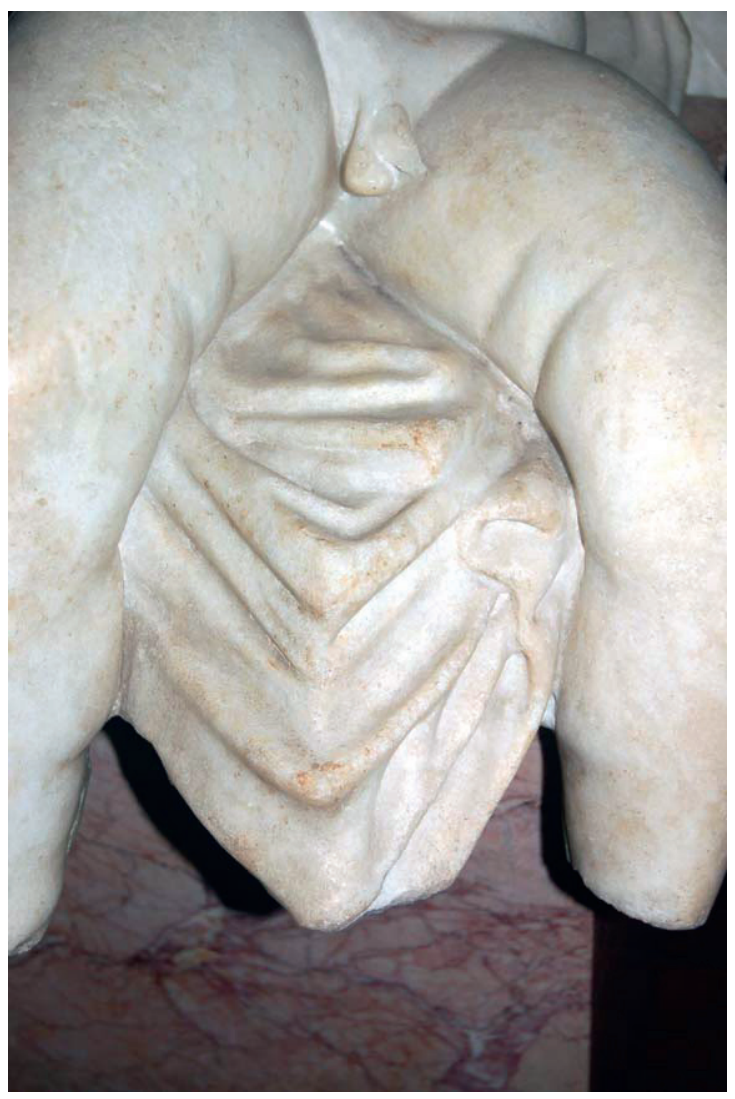

Fig. 15. Detail of the drapery between the legs of the marble Capitoline Sleeping Eros in fig. 12. (C) S. Hemingway.

\section{A New Genre: Representations of Sleep in Hellenistic Sculpture}

Images of figures sleeping occur in small-scale sculptures and vase paintings of the Classical period. Especially popular at the time were scenes of sleeping maenads being approached by satyrs, such as depicted on an Attic red-figure lekythos attributed to Polion. The vase represents a naughty satyr peaking under the chiton of one sleeping maenad (fig. 16) ${ }^{48}$. There is a significant shift in the Hellenistic period, when artists began to explore various aspects of sleep in large-scale sculptures. These works were part of a trend in Hellenistic art that favored realism and new representations of cognitive thought ably expressed in portraits of historic individuals as well as mythological figures. A magnificent example is the Barberini Faun, which may well be an original Pergamene Greek sculpture of the 3rd or 2nd century B.C., if it is not a fine Roman copy ${ }^{49}$. It was found near Hadrian's Mausoleum in Rome in the 17th century. As with the Sleeping Eros, the viewer becomes a voyeur in the scene, which here has strong Dionysian and sexual overtones. An intriguing recent interpretation identifies the sleeping satyr as the one that wily King Midas captured after it had drunk from a spring spiked with potent wine ${ }^{50}$. The satyr's exposed pose and not completely restful sleep may foreshadow his imminent capture, 


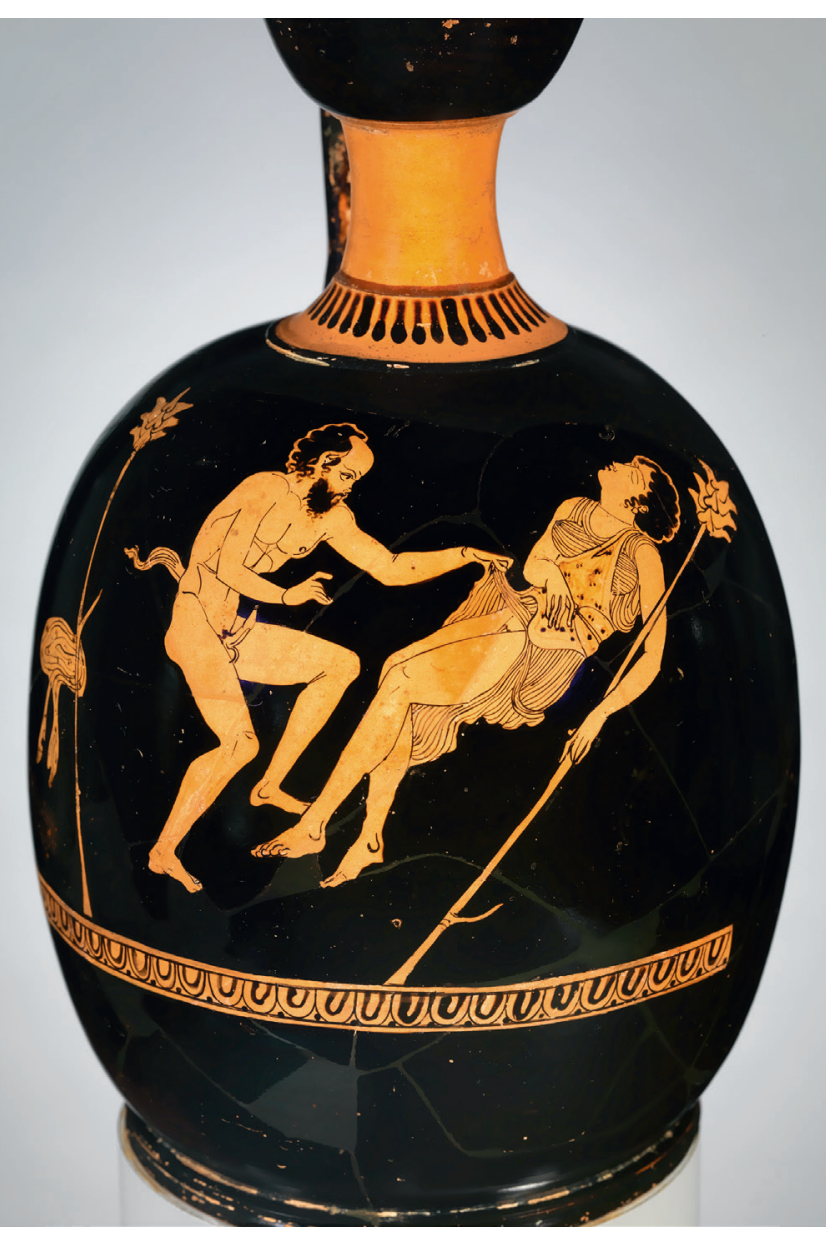

Fig. 16. Squat lekythos with a satyr and a sleeping maenad, Greek, Attic, Classical period, red-figure, ca. 430-410 B.C. Attributed to Polion. Height $20 \mathrm{~cm}$. (C) Collection of Andrés A. Mata, New York.

and the channels conducting water through the rock on which he sits recreated the spring from which he drank. The work may have been commissioned by a Hellenistic king ruling over Phrygia, such as Antiochos IV Epiphanes, who may have wanted to be associated with Midas ${ }^{51}$.

Another major type of sleeping figure is the Sleeping Ariadne. The original is thought to be the work of a Pergamene artist dated to the 3 rd or 2 nd century B.C. ${ }^{52}$ Known from two large-scale marble copies and several variants, the most famous example is the statue in the Vatican, a Hadrianic copy found in Rome in $1512^{53}$. The statue represents Ariadne in a troubled sleep, for when she wakes up she will find that her lover Theseus has abandoned her on the island of Naxos. The statue is also strongly within the Dionysian sphere as, according to the myth, Ariadne wakes to find the god Dionysos, who falls in love with her and takes her as his wife ${ }^{54}$.

Even more surprising is the Sleeping Hermaphrodite, thought to have first been produced in the 3rd or 2nd century B.C. and known in a number of marble $\operatorname{copies}^{55}$. Like the
Barberini Faun, the Sleeping Ariadne and the Sleeping Eros, the Sleeping Hermaphrodite can stand alone and need not belong to a group. As with the Ariadne, he is in a troubled sleep indicated by the way he shifts his weight from one side to the other. Indeed, scholars have suggested that the ancient viewer may have initially believed that he was gazing upon a Sleeping Ariadne ${ }^{56}$. The Sleeping Hermaphrodite is highly erotic from one side, he looks like a beautiful woman, but from the other side he exposes his male genitalia. This theatrical dual presentation brings the viewer into the experience but with unexpected results. One scholar has identified the figure as the androgynous offspring of Zeus and Agdis, Agdistis, who so misbehaved that Dionysos eventually got him drunk and castrated him ${ }^{57}$.

Bernard Ashmole has noted similarities between the Sleeping Hermaphrodite and the Sleeping Eros copy in the Capitoline Museums in Rome and argued that they both represent works by the same sculptor, Polykles, mentioned by Pliny (NH 34.80) as the creator of a famous Hermaphrodite ${ }^{58}$. A significant part of Ashmole's argument is based on the treatment of the hair, which differs for the Metropolitan's Sleeping Eros, and many scholars have not found his argument convincing ${ }^{59}$. Nor is the attribution of the Sleeping Hermaphrodite type represented by the copy in the Palazzo Massimo to the Athenian sculptor Polykles certain since Pliny's reference is just to a statue of a Hermaphrodite not a Sleeping Hermaphrodite and other statues of Hermaphrodites are known. Although the connection with Dionysos is not made explicit in the sculpture, Hermaphrodite is represented elsewhere in Dionysian revels and scholars often assert that this sculpture should be seen as assimilating into the Dionysian sphere $^{60}$.

A spectacular monumental Late Hellenistic sculpture is the Blinding of Polyphemus from the Grotto of Tiberius at Sperlonga. Here the Cyclops, like the Barberini Faun, is shown in a deep drunken sleep, the dangers of which are apparent as Odysseus and his band prepare to blind him and escape from his cave. The sculpture was likely made for the Grotto and is dated to the end of the 1st century B.C. ${ }^{61}$ However, large-scale marble statues representing more than one scene from the Homeric cycle were part of the cargo of the Antikythera shipwreck, indicating that such monumental groups were being made already in the first half of the 1st century B.C. ${ }^{62}$

The varied sculptural monuments of sleeping figures from the Hellenistic period demonstrate that Greek artists were interested in exploring sleep as an altered state of consciousness - its different manifestations as well as its consequences. Like the Sleeping Eros, most of the statues appear to have been free-standing works that did not require additional sculptures. Arguably, the most successful of these Hellenistic representations was the Sleeping Eros, of which many more copies survive than of any other sleeping types. It is not possible to date any of these statues with precision, but it is tempting to see the Sleeping Eros as the earliest representation of this genre and, in spite of its charming conceit, it is also in many ways the most radical. 


\section{Interpretation in Light of Later Images of Eros Sleeping}

The Sleeping Eros is different from other representations of sleeping figures since it represents a major deity. To be sure ancient Greeks believed that Sleep could conquer the gods - as in Homer's Iliad, 8.27-32, where Hypnos has power even over Zeus. However, the gods were not often represented as asleep in Greek art. The original Sleeping Eros statue, which, in fact, may be the Metropolitan's bronze sculpture, would have been considered at the time it was made, most likely sometime in the 3rd century B.C., a startling new and ingenious composition for a large-scale representation of the god of love. Eros is represented as sleeping in earlier small-scale works, such as a late fourth-century B.C. terracotta from a child's tomb at Pella in northern Greece ${ }^{63}$. The inclusion of a Sleeping Eros terracotta statuette among other funerary objects interred with the dead occurs again in the Hellenistic period at Myrina in the 1st century B.C. (fig. 17). The Myrina Sleeping Eros statuette relates to the New York Sleeping Eros type - the Eros lies in a similar pose on a rock covered with drapery, yet it has quite a different feel. It includes a downturned torch, an attribute of Eros that has strong funerary connotations. It is apparent, therefore, that the Sleeping Eros as a metaphor of eternal sleep (death) and eternal love was utilized already in the Hellenistic period for burial offerings even though it was only in the Roman Imperial period that the Sleeping Eros became a popular tomb marker. The Hellenistic terracotta statuettes of Sleeping Eros placed in tombs represent a very different context from the large-scale statue since funerary monuments of the Hellenistic period were not typically made of bronze ${ }^{64}$.

A small terracotta sculpture in the Metropolitan's collection presents a very different image of Eros sleeping. It takes the conceit of depicting Eros as a sleeping baby and turns it on its head, a Hellenistic caricature of Eros as an old man. Here Eros is represented as ravaged by time with nothing of the purity of love and innocence evident in the Metropolitan's bronze statue of Sleeping Eros. Rather, it seems to be a comical commentary on love grown old - a curmudgeon with a huge phallus inserted separately but now missing 65 .

There are a variety of possible contexts for a bronze statue like the Sleeping Eros in the Hellenistic period. It may have been set up in a public park, as is known to have existed on Rhodes in the Hellenistic period, or even in a royal garden ${ }^{66}$. To the modern viewer, the Metropolitan's sculpture of Sleeping Eros may look decorative, but its large scale and high quality make a solely decorative function unlikely in the Hellenistic period. More likely, it is a religious sculpture that was dedicated at a sanctuary as an offering to the gods ${ }^{67}$. While there are not many major cult sanctuaries to Eros known in Greece, like the one at Thespiae in Boeotia, Eros was worshipped in

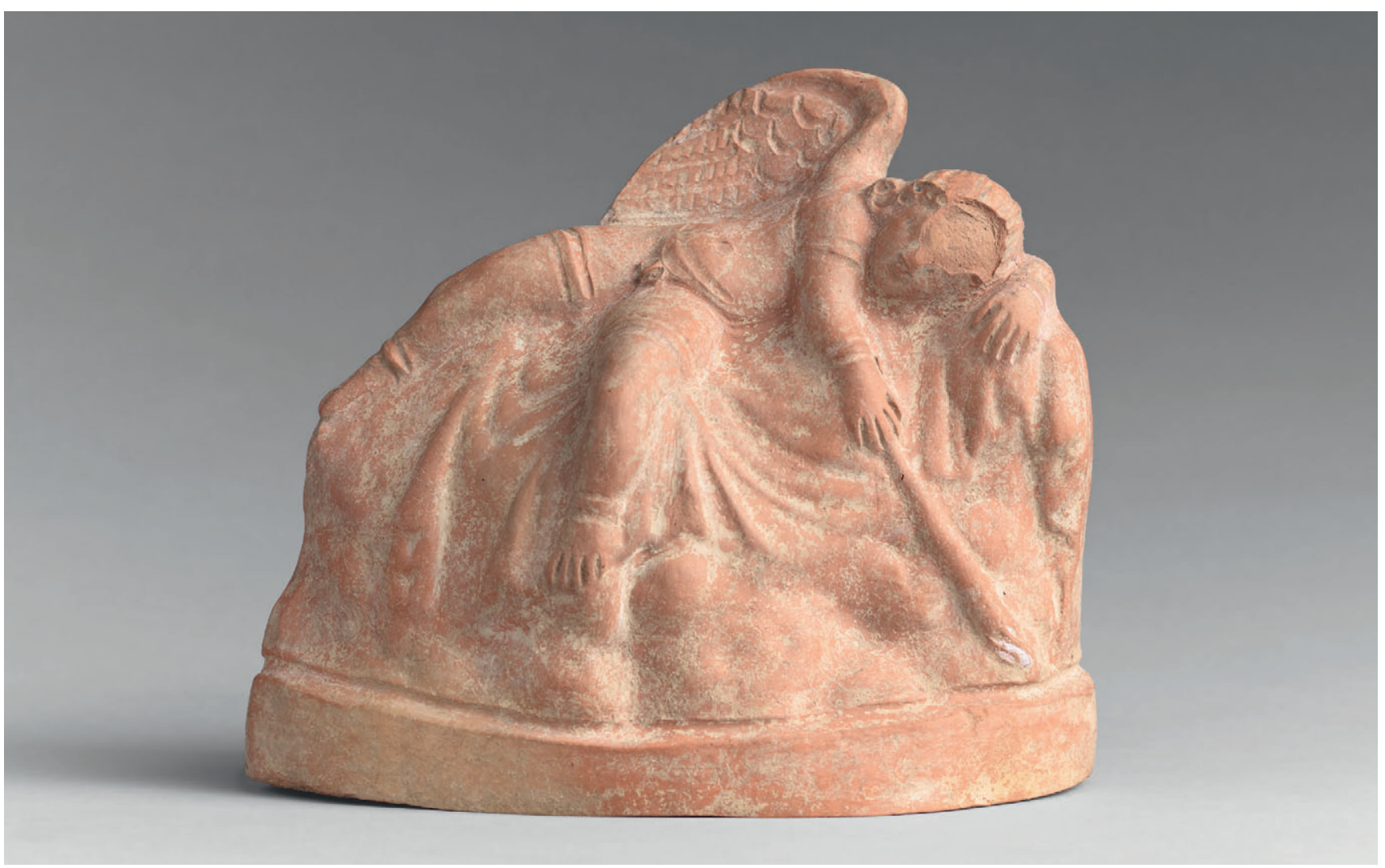

Fig. 17. Statuette of Sleeping Eros from a tomb at Myrina. Greek, Late Hellenistic period, 1st century B.C.

Terracotta. Musée du Louvre, Paris (Inv. MYR 123). @ RMN-Grand Palais (musée du Louvre)/Tony Querrec. 
conjunction with other deities, especially Aphrodite, and a statue of Eros could have been dedicated to her, as well as the god himself. Given the prevalence of the myth of Aphrodite as the mother of Eros in the Hellenistic period, a statue of Eros as a baby may have been seen as especially appropriate. Numerous small-scale terracotta votives representing Eros have been found in Greek sanctuaries. The Metropolitan's Cesnola Collection includes terracotta statuettes of Eros from sanctuaries to Aphrodite, Apollo and Artemis on Cyprus ${ }^{68}$. Religious sculptures intended to delight the gods can appear decorative, especially if their original context is not known. For example, at first glance a Late Hellenistic marble statuette of Aphrodite riding a dolphin appears to be a decorative work but, in fact, it is an ex voto from the sanctuary of Poseidon on Thasos where Aphrodite was also worshipped ${ }^{69}$.

A particularly instructive comparison for the Sleeping Eros is the famous Aphrodite of Knidos by Praxiteles. Considered by Pliny the Elder (A.D. 23-79) to be the finest statue in the world, it was created as a religious work, a cult statue set up in a round temple at Knidos in the 4th century B.C. Highly innovative for its nude representation of the goddess, it is known in over three hundred sculptural copies and variants ${ }^{70}$. Like the Knidian Aphrodite, the Sleeping Eros originally would have been a religious image that became tremendously popular - adapted for a variety of public and private uses as images of religious devotion or decorative garden sculptures. The image of Sleeping Eros adapted well to the minor arts, which added to its widespread circulation. It appears, for example, as a decorative device on a Hellenistic gilt silver bowl of the 2 nd century B.C. ${ }^{71}$

Another useful comparison is a remarkable bronze statue of a dancing satyr in Mazara del Vallo, Sicily ${ }^{72}$. Scholars disagree on its date but the sculpture is arguably a Greek bronze of the late 4th or 3rd century B.C., and was probably originally made as a dedication at a sanctuary ${ }^{73}$. Despite its wild ecstatic pose, the sculpture maintains a reverence that would have been essential to a religious work and its dedicator. This kind of dancing satyr also became a very popular type in later Hellenistic Dionysian and Roman Bacchic imagery ${ }^{74}$. The explicit sensuality of the Dancing Satyr of Mazara del Vallo compares with the bold religious sculptures by the seventeenth-century Roman master Gian Lorenzo Bernini such as the ecstasy of Beata Lodovica Albertoni in the church of San Francesco al Ripa and the ecstasy of Santa Teresa in Cornaro Chapel of Santa Maria della Vittoria, Rome ${ }^{75}$. Brilliant sculptors, who have to work within the confines of their commissions, still manage to create startlingly original compositions. Like the Knidian Aphrodite and the Dancing Satyr of Mazara del Vallo, the sculptor of the original Sleeping Eros created a bold new composition, but one that remained within the strictures of religious dedications.

The notion of art history was first introduced by Hellenistic Greeks. Its study was cultivated at great centers of learning, Alexandria and Pergamon, for example, established through the patronage of the Hellenistic kings, as well as at Athens. The sculptor of the original Sleeping Eros would have been well aware of statues of the god from earlier periods in Greek art. The contrast between Lysippos's statue, where Eros is stringing his bow in preparation for action, and the Sleeping Eros may well have been intentional. Whereas references to Praxiteles's statue of Eros emphasize the god's ardent gaze, the sculptor of the Sleeping Eros achieved a masterpiece in which the eyes of the god are not even open.

Love was a popular theme in bucolic poetry of the Hellenistic age. There are even several references in the Palatine Anthology to sleeping Eros statues, and the need for silence so as not to wake the child. An epigram by Statilius Flaccus, dated to the 1st century B.C. refers cautiously to a Sleeping Eros statue ${ }^{76}$. There is no doubt that most ancient viewers who came upon the Sleeping Eros statue would have immediately thought of the myth of Eros and Psyche, the personification of the human soul, whose story hinges upon a sleeping Eros. In fact, the myth may have been inspiration for the artist who conceived of the Sleeping Eros statue. The connection between Eros and Psyche can be traced back to the Classical philosopher Plato and his ideas on the human soul, as they are set out in Phaedrus, where Psyche acquires wings thanks to Eros. The two mythological beings represent the perfect union of divine love and the human soul. The earliest written account of the story of Eros and Psyche is that of Apulius in The Golden Ass, IV.28-VI.24, from the second half of the 2nd century A.D., although the tale is much older than that. In fact, the image of the child Sleeping Eros was sometimes adapted to illustrate Apulius's account ${ }^{77}$. Interestingly, the myth of Cupid and Psyche is referenced explicitly in one variant of the New York Sleeping Eros type - an Early Imperial Roman marble statue in the Uffizi in Florence (fig. 18), in which a sleeping butterfly rests next to sleeping cupid ${ }^{78}$. The monument is thought to have been a tomb marker. Instead of a bow Cupid holds a bunch of poppy seed capsules in his left hand. Although the figure has sometimes been identified as Somnus or Sleep, the inclusion of the butterfly makes clear that it is Cupid.

Of particular interest for understanding the ancient history of the Met's Sleeping Eros statue are the new results of metallurgical and technical analyses, which indicate that the statue was repaired in antiquity. As there have been few detailed scientific analyses of the cast sections of ancient bronzes there are not many specific parallels to point to, although it is not surprising that such repairs were made in antiquity. The bronze statues of philosophers from the Antikythera shipwreck have some repairs that may have been made long after their initial creation. The statues are considered to be Early Hellenistic Greek works that were being transported from an eastern port such as Delos, Pergamon, or even Ephesos to the West in the 1st century B.C. ${ }^{79}$ More frequent are later variants of popular types like the bronze statue known as the Spinario in the Capitoline Museum in Rome whose body conforms closely to a Hellenistic prototype but whose hair and face reflect the Augustan period in which it was made ${ }^{80}$. If the Metropolitan's Sleeping Eros was created in the 3rd or 2nd century B.C. and restored at a much later 


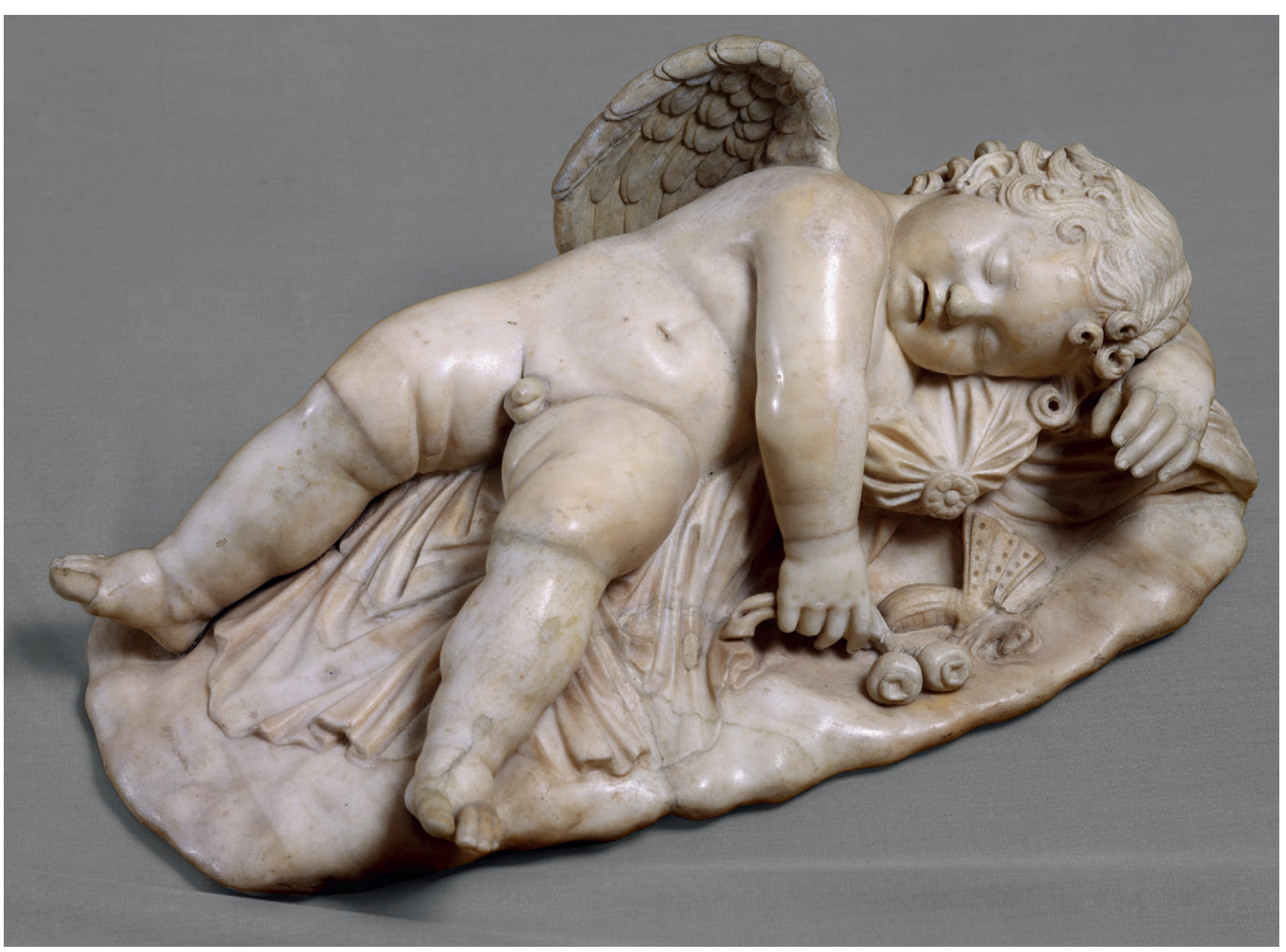

Fig. 18. Statue of Sleeping Eros. Ex. Medici Collection. Roman, Imperial period, 2nd century A.D. Marble. Length 69 cm. Collection of the Uffizi Gallery, Florence (Inv. 1914 n. 392). () Scala/Art Resource, New York.

date, it may well have had more than one ancient context. It may have remained a dedication at a sanctuary, or it may have been removed from that context and entered a private or imperial collection of art. Thousands of major Greek sculptures were looted from sanctuaries and other civic spaces of Greek city-states during the Hellenistic period ${ }^{81}$. Romans paid tremendous sums for Greek sculptures and, at times, would go to extraordinary lengths to acquire them. In Cicero's prosecution of Verres, the notorious Roman governor of Sicily, he notes that Verres stole a marble statue of Eros by Praxiteles from a Roman villa in Messana ${ }^{82}$. Cicero's description of the villa of Gaius Heius of Messana and its rich collection of Greek sculptures, including some set up as private cult statues within shrines created in the home, give a sense of the wealth of such private Roman collections of Greek sculptures and their display. The Villa dei Papiri at Herculaneum is the best known example of an ancient Roman villa in which many of the sculptures in bronze and marble were recovered through excavation. A wide variety of Greek commemorative and votive sculptures appealed to the owner of the villa who incorporated them into decorative displays in many parts of his country estate $^{83}$.
To judge from the number of replicas, the Sleeping Eros and its many adaptations and variations - as Sleeping Cupids and even Somnus, the Roman personification of sleep - were especially popular in the Roman Imperial period. Particularly notable are the wide variety of contexts in which these sculptures were displayed. As in the Hellenistic period, statues of Sleeping Eros continued to be offered as dedications at sanctuaries, but they also decorated Roman public baths, fountains and private villas. Two late epigrams added to the Palatine Anthology refer to a Sleeping Eros sculpture as part of a group with a satyr, which decorated a fountain, the sound of whose waters helped the child sleep ${ }^{84}$. Small-scale statuettes provided an alternative to those who could not afford or did not desire a large-scale statue. The pose of a Sleeping Eros could easily be adapted according to a client's desires, such as a small-scale bronze statuette from Pompeii that likely decorated a private home ${ }^{85}$. Another small-scale marble excavated in a taverna at Ostia, the port city of Rome, surely served a decorative function ${ }^{86}$. The type was well-suited for funerary use and Sleeping Eros/Cupid sculptures became popular tomb monuments, especially those made for children ${ }^{87}$. The image was adapted for a wide variety of uses from its 
appearance in relief on sarcophagi, marble urns, and altars to mosaics, wall paintings, gold jewelry, terracotta lamps, and an array of other objects.

The recovery of ancient sculptures in the Italian Renaissance period, works such as the Laocoon found in the Roman emperor Nero's Golden House in the early 16th century, inspired artists like Michelangelo to adapt classical styles to their own work. The Sleeping Eros was among the earliest types rediscovered and it is known that Michelangelo even made one, which he passed off as an ancient sculpture ${ }^{88}$. Sleeping Eros was the subject of numerous figural studies by Renaissance and Baroque artists in Italy who were looking to the classical tradition for inspiration. Undoubtedly, the most interesting later adaptation of the Sleeping Eros statue is in the Pitti Palace, Florence (fig. 19). It has been interpreted as an allegorical figure of the conquest of carnal passion. While the painting has been argued to be "a token of a great Platonic passion”, the dark pigments and Caravaggio's representation of the child as a boy of the gutters may instead signify the death of love ${ }^{89}$. The figure's pose clearly looks to the ancient type, which was also a popular subject in seventeenth-century Italian poetry ${ }^{90}$. The appearance and evocation of Caravaggio's Sleeping Cupid could not be more different from the Metropolitan's ancient bronze sculpture of the Sleeping Eros.

\section{Conclusion}

Like Caravaggio's Sleeping Cupid, the Metropolitan's Sleeping Eros would have looked incredibly life-like to the ancient viewer (fig. 1). Part of the success of the statue is the way the sleeping figure draws in the viewer to become a part of the scene as he or she looks down at this loveliest of heavenly creatures. They say that children look like angels when they sleep. The artist of the Sleeping Eros has captured that

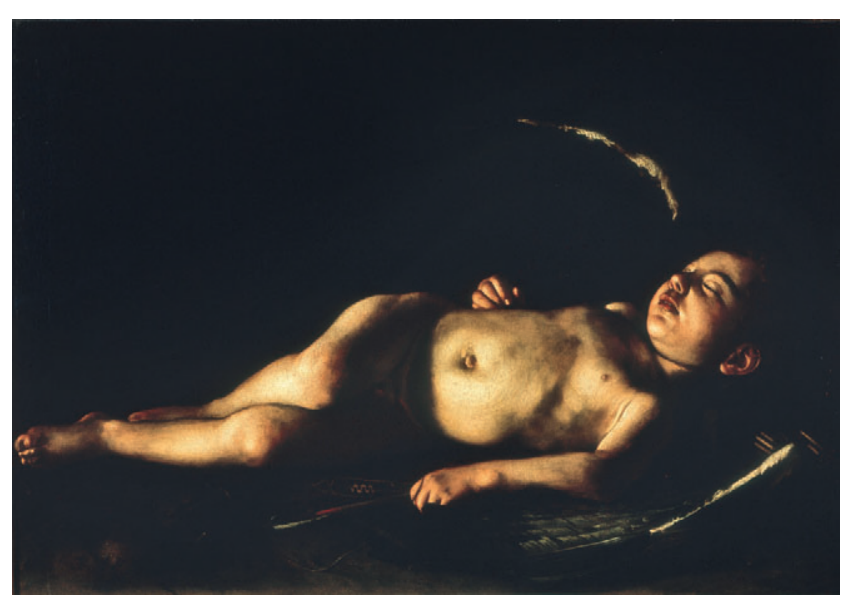

Fig. 19. Caravaggio (Michelangelo Merisi da) (1573-1610), Sleeping Cupid, 1608. Collection of the Pitti Palace, Florence. Photo by Nicola Lorusso. (C) Alinari/Art Resource, New York.

serenity and beauty. Remarkably enough, with its widespread usage in Roman times, the Sleeping Eros is likely to have been one of the major inspirations for the cherubs and putti that become so prevalent in Renaissance and later art. The sleep of the Metropolitan's bronze Eros is not the troubled sleep of the Hermaphrodite or Sleeping Ariadne. The god of love is at peace and the pure innocence of love is clearly represented. Although the quiver around his neck and the presence of his bow allude to his ability to wound, it is not the side of Eros that wins out in this representation. While it is a most unusual representation for a deity, there is precedent for the notion of a sleeping Eros in the myth of Eros and Psyche. The sculpture became one of the most popular sculptural types in Roman times, displayed in baths and nymphaeums as part of fountains as well as in private villas, even tavernas and as funerary monuments.

Comparison of the Metropolitan's Sleeping Eros with other extant examples of the New York type shows it to be a work apart - one of the highest quality. However, the other replicas enable us to restore in the mind's eye the missing elements of the composition, notably the bow and quiver, the placement of the left arm and the missing drapery. The technical analysis proves the statue to be a tour de force of craftsmanship, expertly restored in antiquity, possibly after damages occurred to the drapery between the legs. The repairs may have been made as late as the Early Imperial period given the high lead content of the drapery. When the statue was first made in the Hellenistic period, probably in the 3rd century B.C., the Sleeping Eros was most likely a religious dedication set up at a sanctuary like the famous bronze Eros by Lysippos (see fig. 2) dedicated at Thespiae in Boeotia. In later times, it could have remained in its original location or been removed as a valuable antique Greek sculpture and displayed in a private setting such as a Roman villa.

\section{Remerciements}

Seán Hemingway wishes to thank Thomas P. Campbell, Director, and Carlos A. Picón, Curator-in-Charge of the Department of Greek and Roman Art for their support; Richard Stone and Mark Wypyski for their sterling collaboration; and other colleagues at the Metropolitan Museum including Barbara Bridgers, Carrie Reborah Barratt, Lawrence Becker, Marco Leona, and Julie Zeftel. Part of the research for this essay was undertaken while I was the Metropolitan Museum of Art Visiting Curator at the American Academy in Rome. I am extremely grateful to Cynthia Hazen Polsky, whose generosity makes this fellowship possible and I am grateful to my colleagues at the American Academy in Rome. This research also resulted in the exhibition "Sleeping Eros" on view at the Metropolitan Museum, January 29-June 23, 2013. I am also thankful to the following individuals: Allia Benner, Sophie Descamps-Lequime, Carol C. Mattusch, Claudio Parisi Presicce, Brunilde S. Ridgway, and Andrew Stewart. I especially thank Colette C. Hemingway, who is the Psyche to my Eros, for her encouragement, thoughtful discussions and editing. 
Notes

1. For the Eros statues of Phidias,

Alcamenes and Praxiteles, see Corso 2004, p. 244-256; Pasquier, Martinez, 2007, p. 354356 .

2. The group is mentioned by Pausanias (II.21). See Calcani, 2009, p. 48.

3. On the origins of Eros, see Breitenberger, 2007, p. 137-169. See also Hemingway, 2013, especially p. 30-32.

4. See Pirenne-Delforge, Pironti, 2011 p. 41-53, especially p. 46 .

5. "you cruel child of guileful Aphrodite, whom she bore to... Ares." Simonides, Fragment 575 (Campbell, 1991, p. 461).

6. See, for example, Kondolean, Segal, 2011, p. 64, catalogue number 40, p. 193.

7. Söldner (1986, p. 596-619, catalogue numbers. 3-38) catalogues 35 examples. Four more can be added to her list for the New York type: a Roman marble fountain statue in the Delphi Archaeological Museum; a large marble statuette of unknown provenance, dated to the 2nd century A.D., in the Athens National Archaeological Museum, inv. no. 5753 (Stampolidis, Tassoulas, 2009, p. 156-157, illustrated); a small marble statuette found in Rome in the Tiber River and likely dated to the first century A.D., Museo Nazionale Romano Terme di Diocletio; and an early Imperial small marble statue from a French Private Collection (Christie's New York, 11 June 2003, Sale 1244, lot 168, illustrated)

8. Richter, 1943, p. 377.

9. See Mattusch, 1996, Classical Bronzes, p. 161-163, for a summary of the many different dates within the Hellenistic period assigned to the statue.

10. Marcadé, 1993, p. 482

11. Söldner, 1986, p. 65.

12. Richter, 1943, p. 372-374.

13. Ridgway, 1990 , p. 326-328

14. Hemingway, 2004, p. 13.

15. Mattusch, 1996, Classical Bronzes, p. 165. On technical grounds alone, however, it would be highly unlikely for the statue to be dated any later than the 2nd century A.D. because large-scale Roman bronzes of the 3rd century A.D. and later tend to be much poorer castings with large quantities of lead in their alloys.

16. Burn, 2004, p. 148, fig. 85 .

17. Picón, Mertens, Milleker et al., 2007, p. 451 , no. 240 ; Hemingway, 2007 , p. 50 , fig. 1 , p. 54-55.

18. On the Colossus, see Haynes, 1992, p. 121-128; Clayton, Price, 1989, p. 124-137; Smith, 1991, p. 242, fig. 303

19. On the Hellenistic sculpture of Rhodes, see Merker, 1973; Machaira, 2011; Mattusch, 1998, p. 149-156.

20. See Zimmer, Hackländer, 1997; Gerlach, 2002, especially p. 16-27, figs. 1-2, 11

21. Hemingway, Milleker, Stone, 2002 p. 200-207.

22. See Mattusch, 1996, The Fire of Hephaistos, p. 182-184, illustrated; see also Azema et al. in this volume.

23. See Richter, 1943, p. 371, fig. 7 for an image of the statue prior to cleaning. This work was carried out by the conservato Joseph Ternbach for Joseph Brummer.

24. Richter (1943, p. 370) only identified 5 of these sections. She had not noticed the joins in the legs.

25. The thickness of the bronze in the body is typically between $3-5 \mathrm{~mm}$. In places such as the break in the thumb and the lower part of the upper left wing are considerably thicker. On the lost wax process and piece casting statuary, see Hemingway, 1996, p. 1-8; Hemingway, 2000, p. 37-46.

26 . The chaplet hole in the head and abdomen are $3.4 \mathrm{~mm} \times 3.4 \mathrm{~mm}$. A second chaplet hole in the body near the left arm is $4.0 \mathrm{~mm} \times 4.0 \mathrm{~mm}$. The ones in the drapery and legs are of a similar size.

27. This part of the drapery still has a

layer of burial accretion on its underside. 28. See Mattusch, 1996, The Fire of

Hephaistos, p. 279, fig. 35n.

29. The hammered patch measures $12.3 \mathrm{~mm} \times 10.5 \mathrm{~mm}$

30 . The channel is $53.4 \mathrm{~mm}$ long and 5.1-5.5 mm wide.

31. Mertens (1985, p. 52) also notes that the way the statue "was made shows that it had a separate base, most likely of stone".

32. Hellenistic bronze sculptors were known to use other materials in their bronze sculptures to make them more lifelike. Smith (1991, p. 140) notes that marble bases in the form of rocks for Hellenistic bronze statues have been found on Delos and at Kamiros on Rhodes.

33. Bronze head of Sleeping Eros from Volubilis, Roman copy, 1st or 2nd c. A.D., Rabat Archaeological Museum, accession number Vol. 172. See Boube-Piccot, 1991, p. 58-59, illustrated. Not enough is preserved to attribute it to a specific type.

34.The body of the bronze Eros from Epiais-Rhus was first discovered in 1961 in a second-century A.D. Roman villa, see Piganiol, 1961 , p. 295-297, fig. 20. Its wing came to light in a later salvage excavation at the site, see Fleury, 1977, p. 327-328, fig. 11. See also Söldner, 1986, p. 619-620, figs. 48-49. I am grateful to Sophie Descamps-Lequime for assisting me in examination of the bronze Eros from Epius-Rhus at the Louvre in 2009

35. A particularly well-preserved example of Hypnos is the small statue in the collection of Shelby White and Leon Levy, New York. See Mattusch, 1996, Classical Bronzes, p. 151-160, esp. fig. 5.5; Mattusch, 1996, The Fire of Hephaistos, p. 244, fig. 27d. For the Salamis Youth, now in the Antikensammlungen, Berlin and dated to the Early Augustan period, see Heilmeyer, 1996, especially p. 43, pl. 8. For the head of an athlete in the DeMenil Collection,

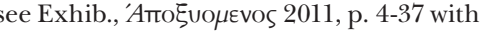
previous bibliography. Another bronze copy of the type was found off the coast of Croatia in 1999. Interestingly, it also exhibits the same joining technique for the head and has been dated to the 1st century B.C., see Michelucci, 2006, p. 42-43, 46-47, figs. 28-29.

36. The other high lead sample (sample 6) was taken from an excrescence on the interior of the left leg that is excess metal from the joining of the drapery to the left leg.

37. On the alloy of Hellenistic bronze sculptures, see Mille et al., 2012, fig 34; Hemingway, 2004, p. 149. For a compendium of analyses of Roman Imperial bronzes, see Lahusen, Formigli, 2001, p. 471-478.

38. Giustozzi, 2007, p. 47

39. Although the naturalistic wings of the
Metropolitan's Sleeping Eros, which lie closed like a bird's wings, are not as common as the Capitoline variant, there are other examples from the series as on a small statuette from the Tiber in the Museo Nazionale Romano, and on a first-century A.D. marble statue from Paphos, Cyprus. See Söldner, 1986, p. 606 , catalogue number 18 , fig. 18 .

40. For the statue from Paphos, see Söldner, 1986, p. 606, catalogue number 18. For the statue from Delphi, see Marcadè, 1993, p. 475 -484, figs. 1-2.

41. The pose is reversed and the drapery simplified. See Hemingway, 2002, p. 27, illustrated; Hemingway, 2004, p. 7-9, figs. 5-6. 42. A preliminary sketch line for the quiver strap is visible beneath the wing. It must be something like the under drawing or sketch lines that one sometimes sees on Greek vase paintings. Since this strap line would have been covered by the wing, it would not have been visible to the ancient viewer and so the artist left it there

43. The golden tipped arrows of Eros were said to have dove feathers, while the lead tipped arrows had owl feathers. It is not possible to tell what type is represented in the fragment preserved by the god's head. 44. See Söldner, 1986, p. 603-604, catalogue number 15, figs. 20-21.

45. An elaborate quiver appears on a Lysippan replica from Gabii in the collection of the Rome National Museum displayed in the Palazzo Massimo alle Terme, inv. no. 129185. See La Regina, 1998, p. 144-145, illustrated.

46. See Söldner, 1986, p. 65-75, especially the example in the Louvre, fig. 45, which also has the quiver open.

47. Safarik, Zeri, 1990 , p. $154-155$, no. 85 , illustrated. I am grateful to the Colonna family and their curator for enabling me to study this sculpture in the Galleria Colonna in February 2012

48. On representations of sleeping figures in vase paintings from the Classical period, see McNally, 1985, especially p. 155165.

49. Ridgway (1990, p. 313-318, pl. 157) also suggests it is a Roman work in a Hellenistic mode.

50. Sorbella, 2007, "A Satyr for Midas", p. 219-248.

51. See Sorbella, 2007, "A Satyr for

Midas", p. 245.

52. See Ridgway, 1990, p. 330-332.

53. Haskell, Penny, 1981, p. 184-187.

54. See McNally, 1985 , p. $152-192$

55. See Stafford, 1993, p. 11-112; Kondolean, Segal, 2011, p. 128-129, 204 no. 121. On the Roman copies and their significance for a Roman viewer, see

Hemingway, 2006, "Roman Erotic Art", p. 10.

56. See Smith, 1991, p. 133-134; Clayton,

Price, 1989, p. 124-137.

57. Stewart, 1997, p. 230.

58. Ashmole, Beazley, 1932, p. 84

Ashmole, 1922, p. 244-247, fig. 10, pl. X.

59. See, for example, Hermary,

Cassinatis, 1986, "Éros endormi”, LIMC, III.1, 1986, p. 916.

60. Pollitt (1986, p. 149) remains uncertain of the original statue's significance, but suggests that it could have been a serious votive connected with a fertility cult. Although 
the conception of the Sleeping

Hermaphrodite is very contrived, and the

figure's female body and face are idealized, at the root of the representation, which does not appear in Classical art, is an interest in realism, for actual Hermaphrodites certainly did exist in the classical world and would no doubt have fascinated Hellenistic artists who endeavored to represent the human body in its many different manifestations.

61. Other sculptures of sleeping figures from the Hellenistic period include a marble relief of a drunken Sleeping Herakles in the collection of the Bowdoin College Museum of Art (see Kondolean, Segal, 2011, p. 118, no. 100) and a female head from the Ludovisi Collection in Rome identified as Erinys, one of the Fates or Furies, sleeping on the tomb of Agamemnon.

62. See Vlachogianni, 2012, p. 69-70.

63. Descamps-Lequime, 2011, p. 546 , catalogue no. 341, illustrated. See also Stampolidis, Tassoulas, 2009, p. 156 , catalogue no. 125. The appearance of Eros as a tomb offering is linked to the cult of chthonic Aphrodite. See also Pandermalis, 2004, p. 102.

64. Hemingway, 2004, p. 17.

65. Hemingway, 2005, p. 38.

66. Söldner (1986, p. 291-305) suggests it may have been a fountain sculpture in a Dionysian park. On royal gardens in the Hellenistic period, which became increasingly elaborate and ornamental and sometimes included fountains and sculpture, see Bowe, 2010, p. 216-219.

67. It can be compared to other major dedications of bronze statues such as the famous charioteer from Delphi. See Mattusch, 1988, p. 127-135, fig. 6.6; Hauser, Finn, 1983, p. $20-31$.

68. See The Metropolitan Museum of Art, New York, accession numbers 74.51.1595, 74.51.1598, 74.51.1597, 74.51.1599, 74.51.1709, 74.51 .1741 .

69. Vlachopoulos, 2006, p. 90-91, fig. 103. 70. Corso, 2007, p. $9-9-186$, and for the list of 335 extant replicas p. 206-230.

71.See Christie's 2012. p. 138, lot 288 illustrated, a gilt silver bowl whose central medallion has a baby Eros sleeping on a rosette. The motif occurs as early as the first quarter of the 4th century B.C. in a small terracotta (Bielefeld, 1952, p. 51, fig. 2) and must have circulated widely as it recurs in Gandharan jewelry of the 1st-2nd century A.D. See Proser, 2011: p. 91, no. 6. Eros was one of the deities whose image travelled East with Alexander the Great in the 4th century B.C. and which continued East as far as Central Asia influencing local arts. See Tanabe, 2003, p. 20.

72. See Petriaggi, 2003; Pasquier, Martinez, 2007, p. 284-291; Andreae, 2009, p. 7-80.

73. Pasquier, Martinez (2007, 284) suggest 4th c. B.C. or 2nd-1st c. B.C. Andreae argues it is an original by Praxiteles of 4th c. B.C. Corso (2004, p. 170) dates it to the Early Hellenistic period.

74. See, for example, a Roman terracotta plaque with a dancing satyr and maenad, Augustan or Julio-Claudian period, ca. 28 B.C.-A.D. 68 , in the collection of the Metropolitan Museum of Art, New York,
Rogers Fund, 1912, accession number 12.232.8b. See Mertens, 1987, p. 109, catalogue number 79 .

75. See Scribner, 1991, p. 118, pl. 38, p. $90-93$, pl. 25 .

76. See Richter, 1943, p. 372.

77. On the myth, see Rose, 1959, p. 286287. C.S. Lewis wrote a particularly poignant version of the myth. See Lewis, 1956.

78. See Mansuelli, 1958, p. 140, fig. 110.

79. See Vlachogianni, 2012, p. 70, and

see P. Bougia's contribution in this volume.

80. See Exhib., The Spinario, 2005. See

also La Rocca, Presicce, Lo Monaco, 2010 p. 302-303.

81. On the numerous examples of pillage of Greek works by Roman armies during wars of the Hellenistic period, see Pape, 1975, especially p. 6-26. See also Hemingway, 2004, p. 17 , and Miles 2008

82. See Corso, 2010, p. 88-103.

83. See Mattusch, 2005, especially p. 12-19. See also Zanker, 2008, p. 11-21.

84. Greek Anthology 9.586 and 9.587 .

85. Söldner, 1986, p. 742, catalogue number 318, figs. 39-41.

86. Söldner, 1986, p. 606-607, catalogue number 19. This statuette was missing from the storerooms of the Ostia Archaeological Museum in March 2012.

87. See Sorbella, 2007, "Eros and the Lizard", p. 353-370.

88. Unfortunately, his sculpture is lost today. See Norton, 1957, 251-257; Rubenstein, 1986 , p. 257-259; Brown, 2002, p. 109-112, 160172, 177-180, 475-477; Fusco, Corti, 2004, p. $41-52$.

89. Posèq, 1990, p. 162.

90. Cropper, 1991, p. 199-201.

\section{Bibliography}

Andreae B., 2009, Der tanzende Satyr von Mazara del Vallo und Praxiteles, Akademie der Wissenschaften und Literatur, Mainz.

Ashmole B., 1922, "Notes on the Sculptures of the Palazzo dei Conservatori", Journal of Hellenic Studies 42, p. 238-247, pls. VIII-X.

Ashmole B., Beazley J. D., 1932, Greek Sculpture and Painting to the End of the Hellenistic Period, Cambridge University Press, Cambridge.

Bielefeld E., 1952, "Eros in der Blume", $A A$ 1950-1951, p. 47-72

Boube-Piccot C., 1991, "I Bronzi”, in A. Akerraz, A. Touri, M. Habibi, J. Boube, C. Boube-Piccot (eds.), Il Marocco e roma: I grandi bronzi dal museo di Rabat, Edizioni Carte Segrete, Rome, p. 49-120.

Bowe P., 2010, "The evolution of the ancient Greek garden", Studies in the History of Gardens $\mathcal{E}$ Design Landscapes 30.3, p. 208223.

Breitenberger B., 2007, Aphrodite and Eros. The Development of Erotic Mythology in Early Greek Poetry and Cult, Routledge, New York and London.

Brown C. M., 2002, Per dare qualche splendore a la gloriosa cità di Mantua: documents for the Antiquarian collection of Isabella d'Este, Bulzoni, Rome.

Burn L., 2004, Hellenistic Art. From Alexander the Great to Augustus, J. Paul Getty Museum, Los Angeles.
Calcani G., 2009, Skopas di Paros, G. Bretschneider, Rome.

Campbell D. A. (ed. and trans.), 1991, Greek Lyric III. Stesichorus, Ibycus, Simonides, and Others, Harvard University Press, Cambridge, MA.

Christie's, 2012, Christie's London Antiquities Sale Catalogue, Thursday 26 April 2012, Christie's, London.

Clayton P. A., Price M. J., 1989, The Seven Wonders of the Ancient World, Routledge, New York.

Corso A., 2004, The Art of Praxiteles. The Development of Praxiteles' Workshop and its Cultural Tradition until the Sculptor's Acme (364-1 B.C.), "Erma" di Bretschneider, Rome.

Corso A., 2007, The Art of Praxiteles II. The Mature Years, "Erma" di Bretschneider, Rome.

Corso A., 2010, The Art of Praxiteles III. The Advanced Maturity of the Sculptor, "Erma" di Bretschneider, Rome.

Cropper E., 1991, "The Petrifying Art: Marino's Poetry and Caravaggio", MMAJ 26, p. 193-212.

Descamps-Lequime S., Charatzopoulou K. (eds.), 2011, Au royaume d'Alexandre le Grand. La Macédonie antique, éditions du Louvre, Paris.

Exhib. London, 2005: The Spinario [Exhibition. London, The British Museum, 15 March-14 April 2005].

Exhib. Rome, 2011-2012: 'Aто §voнєvos. L'atleta del Kimbell Art Museum [Exhibition. Rome, Capitoline Museum, 24 November 2011-15 January 2012]

Fiore K. H., 1997, Apollo e Dafne del Bernini nella Galleria Borghese, Silvana, Milan.

Fleury M., 1977, “Circonscription de l'Ile-deFrance”, Gallia 35.2, p. 321-334.

Fusco L. S., Corti G., 2004, Lorenzo de'Medici, collector and antiquarian, Cambridge University Press, Cambridge and New York.

Gerlach S., 2002, Der Betende Knabe. Ein Werk aus dem Alten Museum, Antikensammlung, Staatliche Museen zu Berlin Preußischer Kulturbesitz Berlin-Mitte, Museumsinsel, Gebr. Mann, Berlin.

Giumlia-Mair A. (ed.), 2002, I bronzi antichi: Produzione e tecnologia. Atti del XV Congresso Internazionale sui Bronzi Antichi, GradoAquileia 22-26 maggio 2001, Mergoil, Montagnac.

Giustozzi N. (ed.), 2007, Eros. Rome Colosseum, 3 March-16 September 2007, Electa, Milan.

Haskell F., Penny N., 1981, Taste and the Antique: the lure of classical sculpture, 15001900, Yale University Press, New Haven.

Hauser C., Finn D., 1983, Greek Monumental Bronze Sculpture, Thames and Hudson, London and New York, 1983.

Haynes D., 1992, The Technique of Greek Bronze Statuary, P. von Zabern, Mainz am Rhein.

Heilmeyer W.-D., 1996, Der Jüngling von Salamis. Technische Untersuchungen zu römischen Grossbronzen, P. von Zabern, Mainz.

Hemingway S., 1996, "How Bronze Statues Were Made In Classical Antiquity", Harvard University Art Museums Galler Series 19, p. 1-8.

Hemingway S., 2000, "Bronze Sculpture", in R. Ling (ed.), Making Classical Art. 
Process E Practice, Tempus, Charleston, South Carolina, p. 37-46.

Hemingway S., 2002, "Posthumous Copies of Ancient Greek Sculpture: Roman Taste and Techniques", Sculpture Review Magazine 51.2, p. 26-33.

Hemingway S., 2004, The Horse and Jockey from Artemision. A Bronze Equestrian Monument of the Hellenistic Period, University of California Press, Berkeley.

Hemingway S., 2005, "Caricature and the Grotesque in Hellenistic Sculpture", Sculpture Review Magazine 54.2, p. 34-38.

Hemingway S., 2006, "Reflections on the Classical Greek Bronze Caryatid Mirrors", in Stampolides N. (ed.), GENETHLION, Nicholas P. Goulandris Museum of Cycladic Art, Athens, p. 203-210.

Hemingway S., 2006, "Roman Erotic Art", Sculpture Review Magazine 55.4, p. 10-15.

Hemingway S., 2007, "From Gods to Grotesques: Hellenistic Bronze Sculptures at the Metropolitan Museum", Apollo Magazine May, 2007, p. 50-56.

Hemingway S., 2013, "Love Actually", Minerva Magazine, May/June 2013, p. 30-33.

Hemingway S., Milleker E., Stone R., 2002, "The Early Imperial Bronze Statue of a Boy at The Metropolitan Museum of Art: A Technical and Stylistic Analysis", in A. Giumlia-Mair (ed.), I bronzi antichi: Produzione e tecnologia. Atti del XV Congresso Internazionale sui Bronzi Antichi, GradoAquileia 22-26 maggio 2001, Mergoil, Montagnac, p. 200-207.

Kaltsas N., Vlachogianni E., Bougia P. (eds.), 2012, The Antikythera Shipwreck. The ship, the treasures, the mechanism, Kapon Editions, Athens.

Kondolean C., Segal P. C. (eds.), 2011, Aphrodite and the Gods of Love, MFA Publications, Boston.

La Regina A., 1998, Museo Nazionale Romano. Palazzo Massimo Alle Terme, Electa, Milan.

La Rocca E., Presicce C. P., Lo Monaco A. (eds.), 2010, I Giorni di Roma. L'Età della Conquista, Skira, Milan.

Lahusen G., Formigli E., 2001, Römische Bildnisse aus Bronze. Kunst und Technik, Hirmer Verlag, Munich.

Lewis C. S., 1956, Till We Have Faces. A Myth Retold, Harcourt Brace, London and New York.

Hermary A., Cassinatis H., 1986, "Éros endormi”, LIMC, III, Artemis, Zurich, p. $916-917$.

Ling R. (ed.), 2000, Making Classical Art. Process E Practice, Tempus, Charleston, South Carolina.

Machaira V., 2011, Hellenistika glypta tes Rhodou: katalogos, Akadēmia Athēnōn, Athens.

Mansuelli G. A., 1958, Galleria degli Uffizi. Le Sculture, Istituto poligrafico dello Stato, Rome.

Marcadé J., 1993, Études de Sculpture et d'Iconographie Antiques. Scripta Varia, 19411991, Publications de la Sorbonne, Paris.

Mattusch C. C., 1988, Greek Bronze Statuary. From the Beginnings through the Fifth Century B.C., Cornell University Press, Ithaca.

Mattusch C. C., 1996, Classical Bronzes. The Art and Craft of Greek and Roman Statuary, Cornell University Press, Ithaca.
Mattusch C. C., 1996, The Fire of Hephaistos. Large Classical Bronzes from North American Collections, Harvard University Art Museums, Cambridge.

Mattusch C. C., 1998, "Rhodian Sculpture: A School, a Style or Many Workshops?" in O. Palagia, W. D. E. Coulson (eds.), Regional Schools of Hellenistic Sculpture. Proceedings of an International Conference Held at the American School of Classical Studies at Athens, March 15-17, 1996, Oxbow Books, Oxford, p. 149-156.

Mattusch C. C., 2005, The Villa dei Papiri at Herculaneum. Life and Afterlife of a Sculpture Collection, J. Paul Getty Museum, Los Angeles.

McNally S., 1985, "Ariadne and Others: Images of Sleep in Greek and Early Roman Art”, Classical Antiquity 4.2, p. 152-192.

Merker G., 1973, The Hellenistic Sculpture of Rhodes, P. Aström, Göteborg.

Mertens J. R., 1985, "Greek Bronzes in the Metropolitan Museum of Art”, $M M A B$ 43.2, p. 1-65.

Mertens J. R., 1987, The Metropolitan Museum of Art. Greece and Rome, The Metropolitan Museum of Art, New York.

Michelucci M. (ed.), 2006, Apoxyomenos. The Athlete of Croatia, Giunti Editore, Florence.

Miles M. M., 2008, Art as Plunder: The Ancient Origins of Debate about Cultural Property, Cambridge University Press, New York.

Mille B., Rossetti L., Rolley C., avec la collaboration de Bourgarit D., Formigli E. et Pernot M., 2012, « Les deux statues d'enfant en bronze (Cap d'Agde) : étude iconographique et technique ", in Denoyelle M., Descamps S., Mille B. et Verger S. (éds.), Actes du colloque Bronzes grecs et romains, recherches récentes, hommage à Claude Rolley, INHA, 16-17/06/2009, http://inha.revues.org/3949

Norton P. F., 1957, "The Lost Sleeping Cupid of Michelangelo", The Art Bulletin 39.4, p. 251-257.

O. Palagia, W. D. E. Coulson (eds.), 1998, Regional Schools of Hellenistic Sculpture. Proceedings of an International Conference Held at the American School of Classical Studies at Athens, March 15-17, 1996, Oxbow Books, Oxford.

Pandermalis D. (ed.), 2004, Alexander the Great. Treasures from an Epic Era of Hellenism, Alexander S. Onassis Public Benefit Foundation, New York.

Pape M., 1975, Griechische Kunstwerke aus Kriegsbeute und ihre öffentliche Aufstellung in Rom: Von der Eroberumng von Syrakus bis in augusteische Zeit, unedited Ph.D. dissertation, University of Hamburg, Hamburg.

Pasquier A., Martinez J.-L. (eds.), 2007, Praxitèle, Somogy, Paris.

Petriaggi R. (ed.), 2003, Il Satiro Danzante, Leonardo International, Milan.

Picón C. A., Mertens J. R., Milleker E. J., Lightfoot C. S., Hemingway S. and De Puma R., 2007, Art of the Classical World in the Metropolitan Museum of Art, The Metropolitan Museum of Art, New York.

Piganiol A., 1961, "Circonscription de Paris (Région Nord)”, Gallia 19.2, p. 283-309.
Pirienne-Delforge V., Pironti G., 2011, "Greek Cults of Aphrodite", in Kondolean C. Segal P. C. (eds.), Aphrodite and the Gods of Love, MFA Publications, Boston, p. 41-62.

Pollitt J. J., 1986, Art in the Hellenistic Age, Cambridge University Press, Cambridge.

Posèq A. W. G., 1990, "Caravaggio and the Antique", Artibus et Historiae 11.21, p. 147167.

Proser A. (ed.), 2011. The Buddhist Heritage of Pakistan: Art of Gandhara, Asia Society, New York

Richter G. M. A., 1943, "A Bronze Eros", American Journal of Archaeology 47.4, p. 365-378.

Ridgway B. Sismondo, 1990, Hellenistic Sculpture I. The Styles of ca. 331-200 B.C., University of Wisconsin Press, Madison.

Rose H. J., 1959, A Handbook of Greek Mythology, Dutton, New York.

Rubinstein R., 1986, “Michelangelo's Lost Sleeping Cupid and Fetti's Vertumnus and Pomona", Journal of the Warburg and Courtauld Institutes 49, p. 257-259.

Safarik E., Zeri F. (eds.), 1990, Catalogo della Galleria Colonna in Roma: Sculture, Busto Arsizio, Bramante.

Scribner C., 1991, Gian Lorenzo Bernini, H. N. Abrams, New York.

Smith R. R. R., 1991, Hellenistic Sculpture. A Handbook, Thames and Hudson, London and New York.

Söldner M., 1986, Untersuchungen zu liegenden Eroten in der hellenistischen und römischen Kunst, 2 volumes, Lang, Frankfurt am Main.

Sorbella J., 2007, "A Satyr for Midas: The Barberini Faun and Hellenistic Royal Patronage", Classical Antiquity 26.2, p. 219-248.

Sorbella J., 2007, "Eros and the Lizard: Children, Animals, and Roman Funerary Sculpture", Hesperia Supplements, Vol. 41, Constructions of Childhood in Ancient Greece and Italy, p. 353-370.

Stafford E. J., 1993, "Aspects of Sleep in Hellenistic Sculpture", Bulletin of the Institute of Classical Studies 38, p. 105-120, pls. 10-11.

Stampolidis N. (ed.), 2006, GENETHLION, Nicholas P. Goulandris Museum of Cycladic Art, Athens.

Stampolidis N., Tassoulas Y., 2009, EROS. From Hesiod's Theogony to Late Antiquity, Nicholas P. Goulandris Museum of Cycladic Art, Athens.

Stewart, A. F., 1997, Art, Desire, and the Body in Ancient Greece, Cambridge University Press, Cambridge.

Vlachogianni E., 2012, "Sculpture. Gods and Heroes from the Depths of the Sea", in Kaltsas N., Vlachogianni E., Bougia P. (eds.), The Antikythera Shipwreck. The ship, the treasures, the mechanism, Kapon Editions, Athens, p. 62-115.

Vlachopoulos A. G. (ed.), 2006, Archaeology. Aegean Islands, Melissa Publishing House Athens.

Zanker P., 2008, Roman Art, J. Paul Getty Museum, Los Angeles.

Zimmer G., Hackländer N., 1997, Der Betende Knabe: Original und Experiment, P. Lang, Frankfurt am Main. 